\title{
ANALISIS RANTAI NILAI BESI BAJA DI INDONESIA
}

\author{
Value Chain Analysis of Iron Steel in Indonesia
}

\author{
IJANG SUHERMAN dan RIDWAN SALEH \\ Puslitbang Teknologi Mineral dan Batubara \\ Jalan Jenderal Sudirman 623 Bandung 40211 \\ Telp. (022) 6030483, Fax. (022) 6003373 \\ e-mail: ijang.suherman@esdm.go.id
}

\begin{abstract}
ABSTRAK
Peningkatan nilai tambah (PNT) sebagaimana diamanatkan dalam UU RI No. 4/2009, bertujuan untuk memberikan keuntungan bagi seluruh pemangku kepentingan, baik bagi perusahaan tambang, industri hilir, masyarakat dan pemerintah. Potensi pasar produk olahan berbasis besi baja baik secara global maupun nasional, belum bisa dimanfaatkan secara optimal. Kebutuhan domestik masih banyak yang dipenuhi dari impor, upaya pengolahan dan pemurnian bijih besi di dalam negeri masih menghadapi permasalahan sehingga masih banyak mata rantai industri hulu-hilir yang terputus. Penelitian ini bertujuan memetakan rantai pasokan beserta aliran produknya dan kaitannya dengan identifikasi permasalahan, menganalisis perkembangan produk dalam rantai nilai, menganalisis kinerja rantai industri, serta dampaknya terhadap perekonomian nasional. Dengan demikian upaya peningkatan keterkaitan industri hulu dan hilir besi baja melalui program PNT, sebagaimana yang diamanatkan dalam UU No.4 Tahun 2009 dapat berjalan sebagaimana yang telah ditetapkan. Pendekatan penelitian dilakukan melalui survei langsung maupun tidak langsung. Hasil penelitian menunjukkan pada rantai industri hulu, yaitu rantai pengolahan bijih besi menjadi sponge iron masih ada tantangan inovasi teknologi yang berbahan baku bijih besi berkadar rendah. Pada rantai industri hilir, yaitu rantai industri baja kasar/semi finished product perkembangannya mengandalkan bahan baku sponge iron impor. Apabila tantangan tersebut dapat diatasi dan investasi dapat terealisasi, maka pada 2020, diperkirakan akan tercipta total nilai ekonomi sekitar USD 15,632 miliar, nilai tambah USD 1,707 miliar, dan serapan tenaga kerja sekitar 90.898 orang. Kontribusi terhadap perekonomian nasional dapat mendongkrak Produk Domestik Bruto sekitar 0,203\%.
\end{abstract}

Kata kunci: Nilai tambah, rantai nilai, kebutuhan domestik, pengolahan dan pemurnian, keterkaitan hulu hilir.

\begin{abstract}
Increase in added value as mandated in Indosenia Law no. 4/2009, aims to provide benefits for all stakeholders, for mining companies, forward industry companies, the community and the government. The market potential of processed products based on iron both globally and nationally, can not be utilized optimally, domestic demand is still largely fulfilled from imports, processing and refining of iron ore in the country still faces problems, so there are still many backward-fordward linkages that are cut off. This research aims to map the supply chain along with the flow of its products and its relation to the identification of problems, analyze product development in the value chain, analyze the performance of the industrial chain, and its impact on the national economy. Thus efforts to increase the backward and forward linkages of industries through the PNT program, as mandated in Law No.4 of 2009 can be run as predetermined. The research approach is done either through direct or indirect survey. The results showed that in the upstream industrial chain of iron ore processing chain into sponge iron there is still a challenge of technological innovation made from low grade iron ore. In the downstream industry chain, the industrial chain of coarse steel / semi-finished products rely on imported sponge iron raw materials. If the challenge can be overcome and investment can be realized, then by 2020, it is expected to create a total economic value of about USD 15.632 billion, value added USD 1.707 billion, and labor absorption of about 90,898 people. Contributions to the national economy can boost Gross Domestic Product by about $0.203 \%$.
\end{abstract}

Keywords: Value added, value chain, domestic demand, processing and refining, backward fordward linkages. 


\section{PENDAHULUAN}

Amanat dari kebijakan Peningkatan nilai tambah (PNT) dalam Undang-Undang Republik Indonesia Nomor 4 Tahun 2009 (UU RI No. 4/2009), yaitu bagi perusahaan tambang berupa peningkatan nilai jual produk olahan; bagi perusahaan industri manufaktur berupa ketersediaan bahan baku yang berasal dari dalam negeri yang diharapkan lebih murah dan terjamin; bagi masyarakat luas berupa ketersediaan lapangan kerja dan kesempatan berusaha; dan bagi pemerintah berupa peningkatan penerimaan Negara (Presiden Republik Indonesia, 2009). Kebijakan PNT melalui pengolahan dan pemurnian di dalam negeri yang telah bergulir mulai 12 Januari 2014 ini belum optimal, sehingga pemerintah mengeluarkan kebijakan relaksasi selama tiga tahun hingga tahun 2017 dan disusul lagi oleh kebijakan relaksasi selama lima tahun hingga tahun 2022, namun dengan persyaratan yang harus dipenuhi.

Hingga saat ini proses pengolahan dan pemurnian melalui pembangunan smelter berjalan lambat, khususnya smelter besi, sehingga tujuan yang ditetapkan dengan adanya kebijakan PNT, masih jauh dari yang diharapkan. Secara umum, tumbuhnya industri besi baja nasional belum mampu memenuhi kebutuhan dalam negeri, akibatnya impor bahan baku dan produk besi baja terus meningkat. Hal tersebut menjadikan kurang kokohnya fundamental industri baja nasional (Pardiarto, 2009). Namun di sisi lain, kondisi tersebut merupakan keuntungan bagi pengembangan iron making plant (Pardiarto, 2011). Hal tersebut menunjukkan bahwa rantai industri besi baja di Indonesia masih banyak yang terputus. Syarat mutlak membangun struktur industri yang kuat, dicirikan dengan kelengkapan mata rantai industri dari hulu hingga hilir, dan keterkaitan yang kuat di antara mata rantai itu (Kementerian Perindustrian, 2013). Oleh karena itu, melalui pendekatan analisis rantai nilai (value chain) besi baja, diharapkan terpetakannya rantai pasokan besi baja beserta aliran produknya dalam rangka optimalisasi keterkaitan hulu dan hilir. Hal ini terkait juga dengan analisis Suherman (2016), mengenai teknoekonomi pengembangan pabrik peleburan bijih besi dalam rangka memperkuat industri besi baja di Indonesia. Terintegrasinya mata rantai hulu dan hiilir besi baja di dalam negeri, pada akhirnya akan meningkatkan kontribusi sektor ini terhadap perekonomian nasional. Hal tersebut sejalan dengan studi Hasni dan Manulang (2011) tentang peran industri baja pada ekonomi Indonesia melalui keterkaitannya dengan sektor lain. Tujuan penulisan makalah ini adalah teridentifikasi kondisi ekonomi setiap mata rantai sehingga upaya peningkatan (optimalisasi) keterkaitan hulu-hilir besi baja melalui kebijakan peningkatan nilai tambah sebagaimana diamanatkan dalam UU No. 4 Tahun 2009 dan kebijakan turunannya dapat berjalan sebagaimana yang diharapkan.

\section{METODE}

Dalam kegiatan ini, digunakan metode penelitian survei sampling secara langsung ke beberapa perusahaan, antara lain PT Sebuku Iron Lateritic Ores (PT SILO), PT Meratus Jaya Iron \& Steel (PT MJIS), PT Delta Prima Steel (PT DPS), PT Lhoong Setia Mining, PT Indoferro, PT Krakatau Steel (PT KS), PT Krakarat Posco, serta melakukan koordinasi dan pendataan ke intansi terkait. Di samping itu, digunakan metoda penelitian nonsurvei, yaitu dilakukan di studio yang meliputi penelusuran referensi yang mutakhir antara lain perkembangan perusahaan pertambangan di Morowali, pengolahan dan analisis. Pengumpulan data menggunakan teknik observasi dan wawancara berpanduan (interview guide), sedangkan model pengolahan dan teknik analisis, digunakan pendekatan statistika deskriptif, model analisis trend, dan analisis nilai tambah.

\section{Statistika Deskriptif}

Statistika deskriptif adalah metode statistika yang digunakan untuk analisis data dengan cara mendeskripsikan atau menggambarkan kecenderungan suatu gugus data yang disajikan dalam grafik atau tabel. Untuk memudahkan penyajian data yang dimaksud, digunakan Program Excell.

\section{Model Perhitungan Nilai Tambah}

Peningkatan nilai tambah didefinisikan sebagai suatu proses pengolahan hasil tambang (baik yang dilakukan satu tahap, maupun beberapa tahap) yang bertujuan 
untuk menghasilkan suatu produk atau komoditas, sehingga nilai ekonomi dan daya gunanya meningkat lebih tinggi dari sebelumnya, serta aktivitas yang ditimbulkan akan memberikan dampak positif terhadap perekonomian dan sosial baik bagi daerah operasional, pusat, maupun daerah non operasional (Suherman dkk., 2011).

Salah satu teori ekonomi untuk menghitung nilai tambah mineral ini adalah "pendekatan pendapatan". Dalam pendekatan pendapatan ini, nilai tambah dari setiap kegiatan ekonomi dihitung dengan jalan menjumlahkan semua balas jasa faktor produksi, yaitu upah dan gaji, surplus usaha, penyusutan dan pajak tidak langsung neto. Untuk sektor pemerintahan dan usaha-usaha yang sifatnya tidak mencari untung, surplus usaha tidak diperhitungkan. Yang termasuk dalam surplus usaha adalah bunga, sewa tanah dan keuntungan.

\section{TINJAUAN PUSTAKA}

\section{Ketersediaan Potensi Besi}

\section{Potensi Sumber Daya dan Cadangan}

Berdasarkan data dari Pusat Sumber Daya Mineral Batubara dan Panas Bumi (2017), potensi sumber daya dan cadangan besi
Indonesia terpusat di Sulawesi Tengah, Maluku Utara, Aceh, Kalimantan Barat, Kalimantan Tengah, Jambi, Kalimantan Selatan dan Sumatera Selatan. Jumlah sumber daya dan cadangan untuk masing-masing daerah tersebut diperlihatkan pada Gambar 1. Berdasarkan penyelidikan geomagnetik di Kabupaten Katapang, Kalimantan Barat, serta pemodelan 3-D suseptibilitas, diperoleh volume magnetik $410.000 \mathrm{~m}^{3}$ atau 1.000.400 ton (Purnama dan Subarna, 2016). Potensi bijih besi di wilayah Indonesia memiliki karakteristik yang beragam, baik dari segi kualitas maupun jenis mineral besi yang terkandung di dalamnya.

Kualitas bahan baku bijih besi Indonesia masih menjadi kendala dalam program pengembangan industri baja nasional berbasis bahan baku lokal. Kualitas bijih besi Indonesia masih belum dapat memenuhi kriteria kualitas yang dibutuhkan industri baja pengguna bahan baku ini. Kualitas bijih besi di Indonesia relatif mempunyai kandungan $\mathrm{Fe}$ tidak terlalu tinggi, meskipun di beberapa tempat ada yang kandungannya di atas 70\% Fe, namun sebaran yang berupa spot-spot dengan kuantitas kecil. Rata-rata kandungan Fe untuk besi primer 47,144\%, pasir besi mempunyai kandungan Fe rata-rata $47,08 \%$ dan besi laterit mempunyai kandungan Fe rata-rata 30,26\% (Usman, 2015).

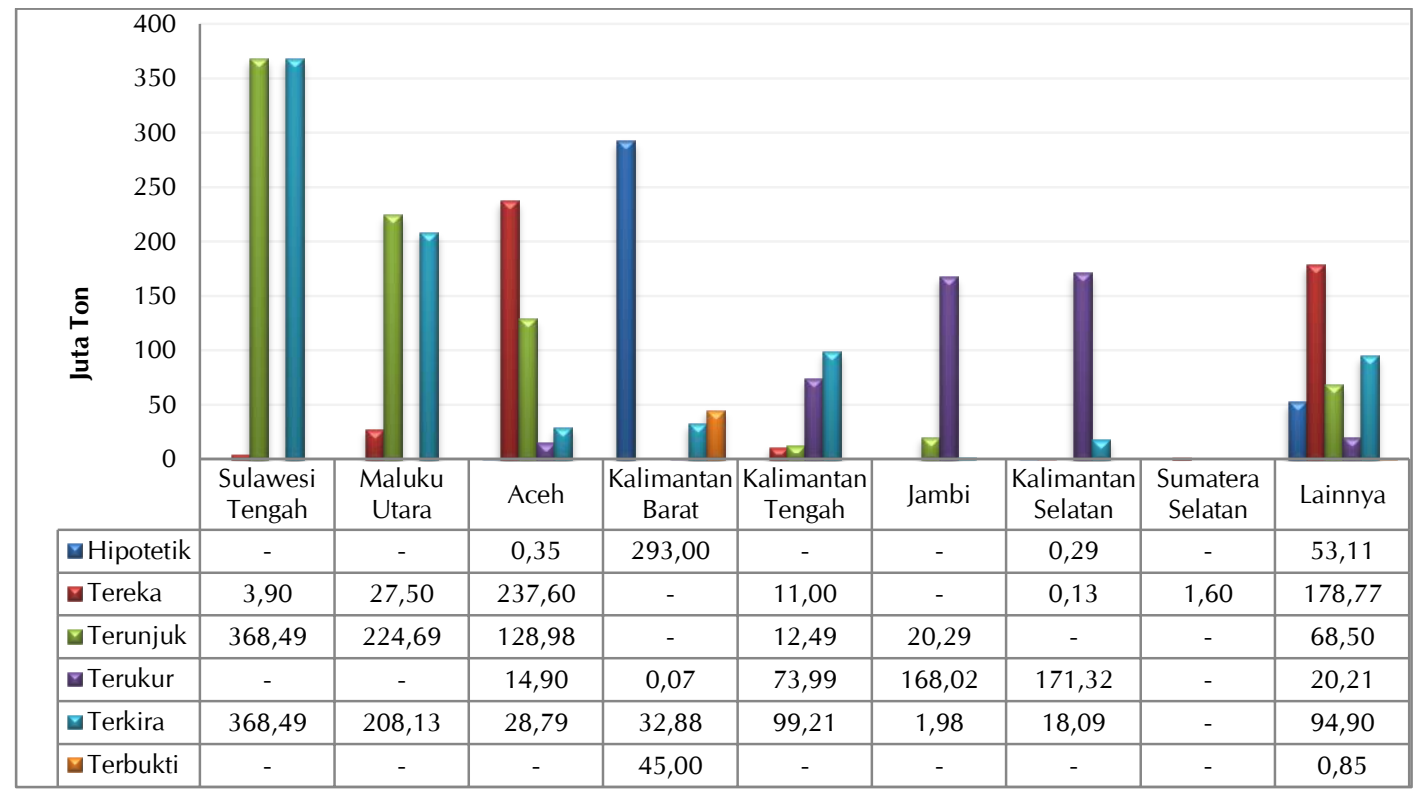

Sumber : Pusat Sumber Daya Mineral Batubara dan Panas Bumi (2017) (diolah kembali)

Gambar 1. Sebaran sumber daya dan cadangan besi Indonesia, status 2016 


\section{Perkembangan Pasar Besi-baja Dunia}

Produksi bijih besi dunia pada 2017 mencapai 2,380 miliar ton, turun 43 miliar dari tiga tahun sebelumnya. Hal tersebut dikarenakan China melakukan pemangkasan produksi dari 1.510 juta ton menjadi 340 juta ton. Dengan demikian yang memproduksi bijih besi terbesar di dunia adalah Australia, Brazil, masing-masing sebesar 880 juta ton dan 440 juta ton (Tabel 1). Tingginya produksi ketiga negara tersebut, yaitu Australia, Brazil dan China didukung oleh cadangan bijih yang dimilikinya, yaitu 50 miliar ton, 23 miliar ton dan 21 miliar ton bijih besi. Meskipun dalam tahun terakhir anjok, dalam 7 tahun terakhir, rata-rata produksi bijih besi dunia meningkat sekitar 1,35\%.

China bukan saja mendominasi dunia sebagai produsen tambang bijih besi, tetapi juga di industri pengolahan dengan produk besi kasar/mentah (pig iron) dan baja kasar/mentah (raw steel). Dari jumlah poduksi pig iron dunia sebesar 1,150 miliar ton, di antaranya sebesar 685 juta ton atau 59,57\% diproduksi China pada 2016, sedangkan Jepang pesaing terdekatnya hanya memproduksi 81 juta ton. Selama 7 (tujuh) tahun (2009-2016) produksi pig iron dunia meningkat rata-rata $3,41 \%$ dan China meningkat sekitar $3,44 \%$ per tahun (Tabel 2). Adapun jumlah poduksi baja kasar dunia sebesar 1,600 miliar ton, di antaranya sebesar 800 juta ton atau 50,0\% diproduksi China. Sedangkan Jepang hanya memproduksi 105 juta ton untuk 2016. Selama 7 (tujuh) tahun (2009-2016) produksi baja kasar dunia meningkat sekitar $3,72 \%$ dan China meningkat sekitar 6,05\% (Tabel 3).

\section{HASIL DAN PEMBAHASAN}

\section{Konsep Rantai Nilai Besi Baja}

Pengembangan industri berbasis besi baja masih menghadapi permasalahan antara lain kebutuhan bahan baku industri masih banyak dipenuhi dari impor demikian pula impor produk hilir (barang jadi) membanjiri pasar domestik, teknologi pengolahan/pemurnian yang masih terkendala dengan kualitas bijih besi yang ada, kontribusi besi baja terhadap perekonomian nasional masih kecil. Salah satu faktor yang menyebabkan kondisi di atas adalah di samping masih terputusnya mata rantai industri hulu-hilir juga belum optimalnya keterkaitan industri hulu-hilir (fordward-backward linkages). Dengan menggunakan analisis rantai nilai atau analisis rantai pasok diharapkan dapat diidentifikasi kondisi ekonomi setiap mata rantai sehingga upaya peningkatan (optimalisasi) keterkaitan hulu-hilir besi baja melalui kebijakan peningkatan nilai tambah sebagaimana diamanatkan dalam UU No. 4 Tahun 2009 dan kebijakan turunannya dapat berjalan sebagaimana yang diharapkan.

\section{Struktur Rantai Industri Besi Baja}

Rantai industri atau pohon industri adalah skema yang menggambarkan diversifikasi produk dalam sebuah industri beserta turunannya. Industri besi baja nasional memiliki pohon atau rantai industri yang lengkap dari proses hulu hingga hilir terkini (Gambar 2). Gambar tersebut disampaikan pihak Indonesian Iron \& Steel Industry Association (IISIA) pada FGD Penyelarasan Road Industri \& Pasar Baja Nasional, 12 Januari 2015 di Jakarta.

Rantai industri mencerminkan skema proses produksi besi baja. Dimulai dari sektor paling hulu yakni penambangan bijih besi sebagai bahan baku utama pembuatan besi baja, dilanjutkan dengan proses ore dressing yang menghasilkan konsentrat (iron ore concentrate). Selanjutnya dalam proses aglomeration dihasilkan pellet dan sinter. Pellet dan sinter digunakan sebagai bahan baku pembuatan besi (iron making), menghasilkan sponge iron, hot bricket iron, hot metal, dan pig iron. Untuk menghasilkan produk antara, besi-besi tersebut, dan bahan baku lainnya termasuk scrap, selanjutnya diolah dalam proses steel making \& casting menjadi baja kasar. Produk baja kasar mencakup bloom, billet, slab, dan iron/steel cast. Proses selanjutnya adalah hot forming atau dicanai panas. Dalam tahap ini, billet diolah menjadi round billet, wire rod, dan bar. Slab diolah menjadi hot rolled coil dan plate. Sementara bloom langsung diolah menjadi produk akhir berupa heavy profile dan rail. Setelah melalui tahap hot forming, sebagian produk diproses lebih lanjut melalui cold forming, seperti wire rod yang diolah menjadi wire dan hot rolled coil yang diolah menjadi cold rolled coil. Selebihnya, produk langsung diproses menjadi produk akhir. 


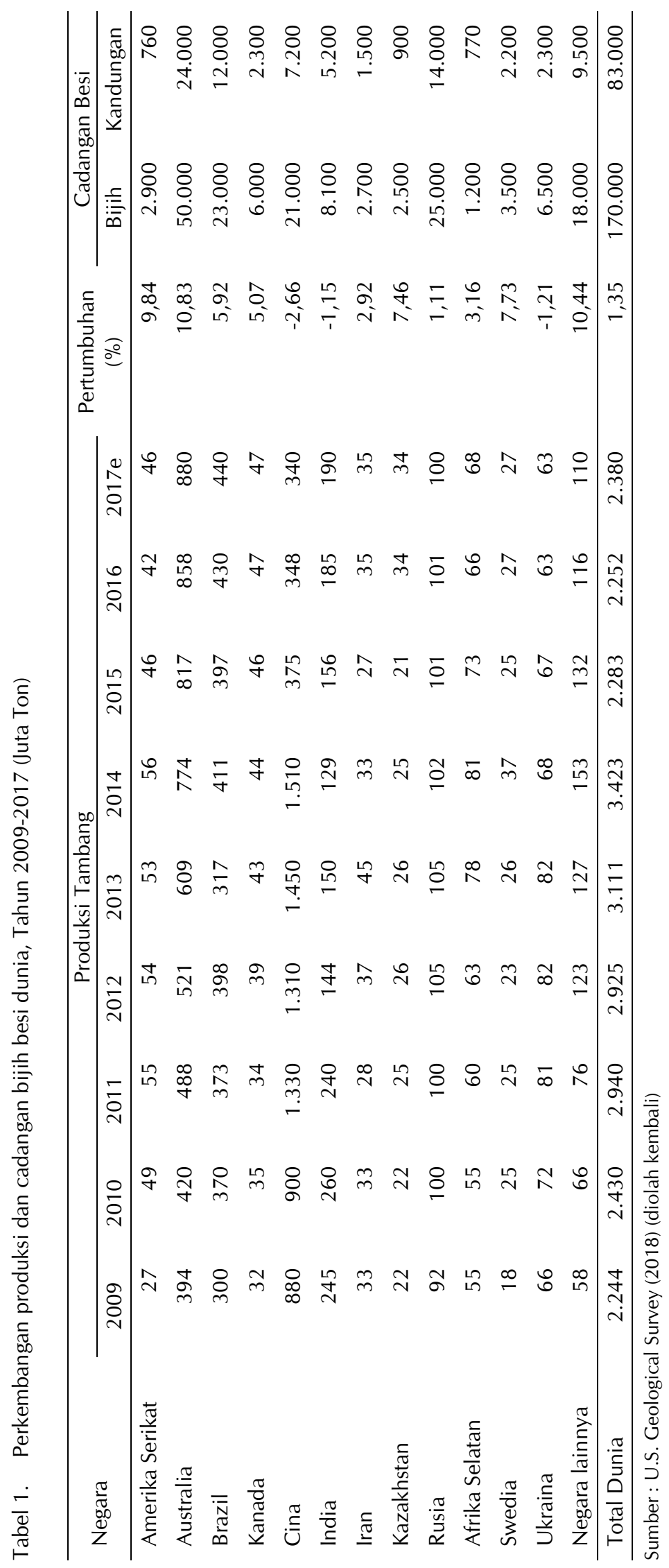




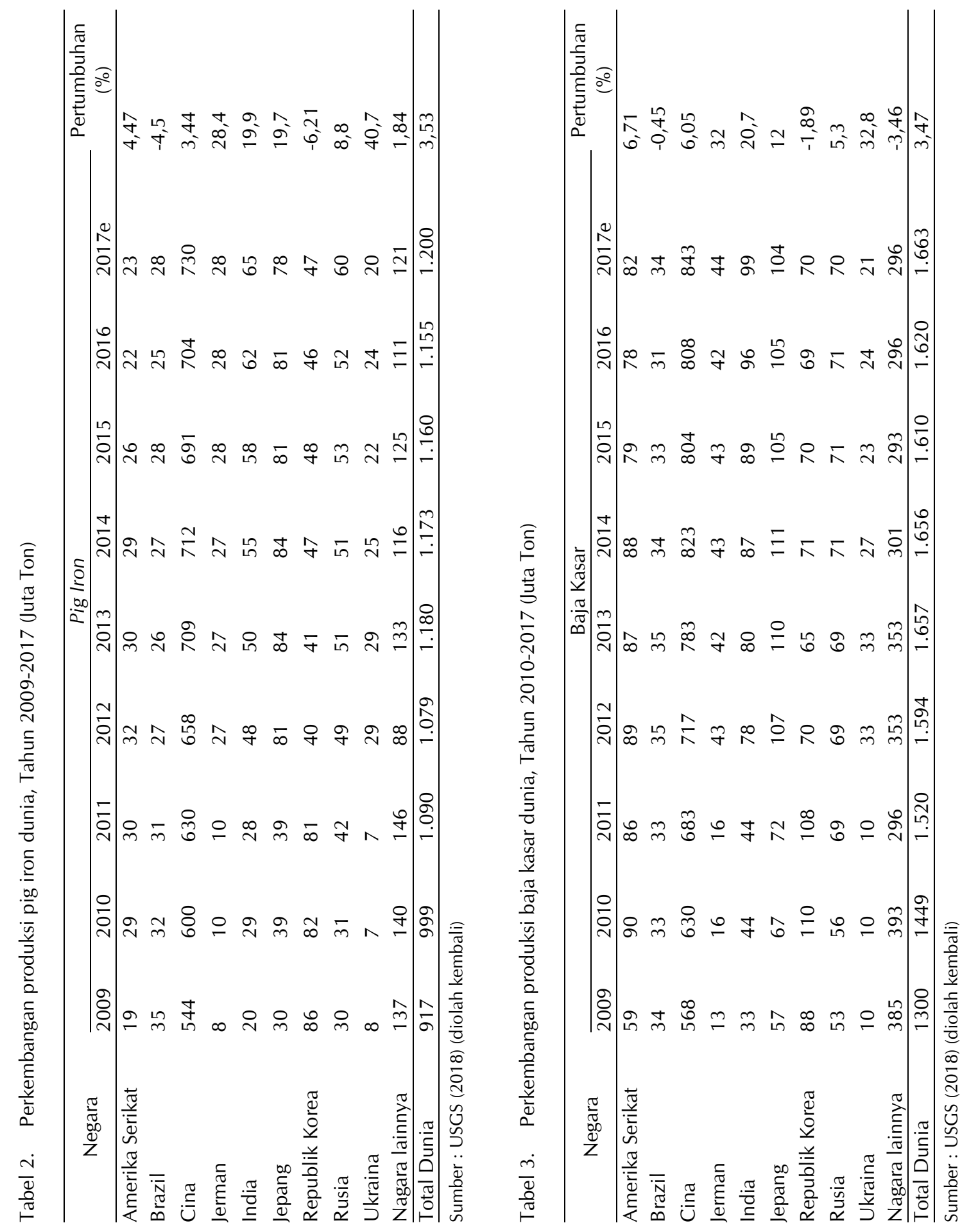




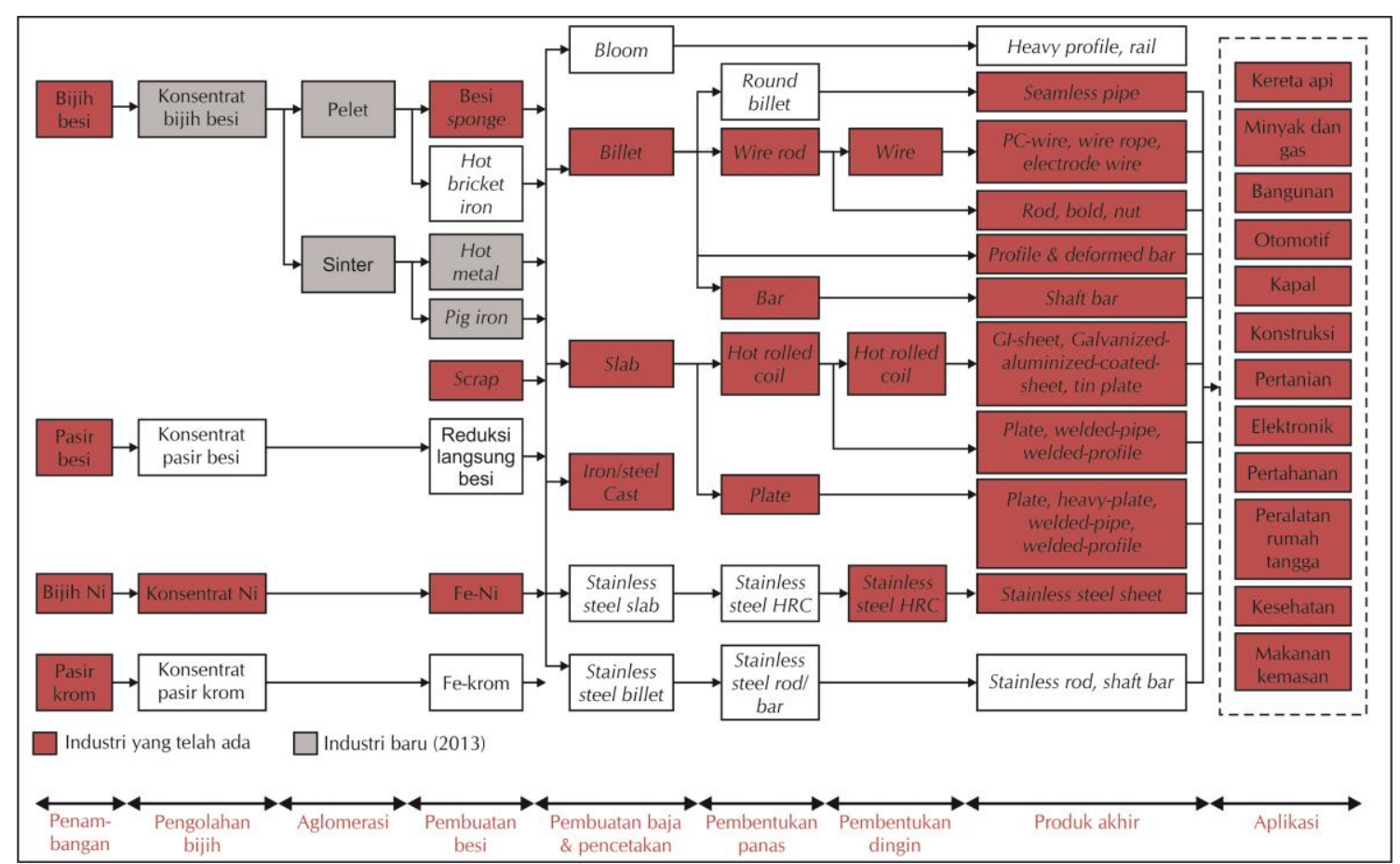

Sumber : Direktur Industri Material Dasar Logam (2015)

Gambar 2. Rantai industri besi baja di Indonesia

Dari gambar struktur rantai industri besi baja tersebut, dapat diketahui sebagian industri yang sudah ada (warna merah) dan sebagain lagi industri yang belum ada (warna putih) serta industri baru/sedang dibangun (warna abu) di dalam negeri. Dengan perkataan lain masih banyak mata rantai industri yang masih terputus, atau masih terputusnya mata rantai industri-hulu hilir berbasis besi baja di dalam negeri.

\section{Analisis Rantai Industri Besi-Baja}

\section{Perkembangan Rantai Pengusahaan Besi-Baja Indonesia}

\section{Bijih Besi}

Sebelum batas waktu larangan ekspor bijih besi yang diamanatkan dalam UU No 4 Tahun 2009, yaitu mulai 12 Januari 2014, perkembangan produksi bijih besi di Indonesia meningkat secara signifikan. Hal ini, di samping disebabkan karena permintaan dunia yang meningkat, juga dipicu oleh dampak adanya kebijakan tersebut. Pada 2009, jumlah ekspor tercatat 8,5 juta ton dengan nilai USD 178 juta dan pada 2013 meningkat dengan sangat signifikan menjadi 22,3 juta ton dengan nilai USD 425 juta. Pada
2014 ekspor bijih besi merosot menjadi 2,1 juta ton dan 2016 sekitar 3,1 juta ton dengan nilai USD 23,3 juta. PT SILO salah satunya perusahaan yang mempunyai program pembangunan smelter, terkadang melakukan ekspor dan terkadang menghentikan ekspornya ke China meskipun sudah mendapatkan surat persetujuan ekspor (SPE). Hal tersebut mengingat harga konsentrat di pasaran jatuh, dari sekitar USD 35 per ton turun menjadi kisaran USD 20 per ton. Pada tahap pengembangan ini PT SILO berencana mengubah jalur produksinya untuk mengolah nikel pig iron (NPI). Target operasional diperkirakan tahun 2017.

Dari sisi impor konsentrat besi trennya berfluktuatif namun cenderung meningkat. Pada 2009 impor konsentrat besi tercatat 1,3 juta ton dengan nilai USD 173,5 juta, kemudian pada 2012 menurun menjadi 0,9 juta ton dengan nilai USD188,9 juta, dan tahun 2016 menjadi 4,2 juta ton dengan nilai 207,2 juta (Gambar 3). Adapun dari sisi harga, ekspor dalam bentuk bijih besi rata-rata sekitar USD 21,6 per ton jauh lebih murah dibandingkan dengan harga impor dalam bentuk konsentrat yang rata-ratanya sekitar USD 177,4 per ton. Dengan kondisi tersebut, neraca perdagangan 
bijih besi tetap defisit, dan nilai tambahnya ada di luar negeri. Kondisi ini sejalan dengan hasil kajian (Haryadi dan Saleh, 2012), bahwa neraca perdagangan luar negeri Indonesia dalam bijih besi selalu defisit.

\section{Besi Sponge (Sponge Iron)}

Perusahaan smelter besi PT MJIS merupakan perusahaan patungan PT KS dengan PT Aneka Tambang, Tbk (Antam). PT MJIS merupakan pabrik pengolahan bijih besi menjadi besi setengah jadi (sponge iron) kapasitas produksi 315 ribu ton per tahun. PT MJIS sudah mulai beroperasi akhir 2012. Proyek industri besi dan baja, Kalimantan Iron making Project, dibangun oleh PT MJIS di Batulicin, Kabupaten Tanah Bumbu, Provinsi Kalimantan Selatan. Hal ini sejalan dengan konsep cluster industry berbasis besi seperti di Kalimantan Selatan (Ishlah, 2009). Pabrik sponge iron ini adalah merupakan pabrik besi yang pertama kali menggunakan bijih besi jenis laterit yang banyak dijumpai di Kalimantan. Pada saat memasuki masa operasi dan komersial PT MJIS membutuhkan karyawan lebih kurang 200 orang, sebagian besar adalah staf operasional yang direkrut dari Kabupaten Tanah Bumbu dan kabupaten lain di Kalimantan Selatan. Penduduk lokal yang direkrut mencapai lebih kurang 55\%. Pabrik sponge iron PT MJIS menggunakan teknologi reduksi langsung
(Direct Reduced Iron) Rotary Kiln dengan reduktor batubara berkapasitas terpasang 315.000 ton per tahun. PT MJIS memproduksi dua jenis sponge iron yaitu sponge iron dengan ukuran 3-22 mm kadar Fe 78\% kapasitas produksi 18.000 ton per bulan dan sponge iron dengan ukuran $<3 \mathrm{~mm}$ kadar Fe $76 \%$ dengan kapasitas produksi 6.000 ton per bulan. PT MJIS berhasil memproduksi Sponge Rotary Kiln (SRK) dan telah dikapalkan ke PT KS (Persero) Tbk (Gambar 4). PT MJIS menggunakan jenis bahan baku lokal, yaitu bijih besi laterit (lateritic iron ore) yang dipasok oleh PT SILO dan bijih besi dari Kalimantan Tengah. Bahan baku bijih besi umumnya berkadar Fe yang rendah, sehingga hasil produksi PT MJIS kurang optimal. PT MJIS mampu menghasilkan produk SRK dengan hasil yang lebih baik, terutama bila sudah mendapatkan pasokan bahan baku dari jenis primary lump ore yang memiliki Fe total di atas $62 \%$. Secara teoritis, primary lump ore dapat menghasilkan SRK dengan Fe Total $>86 \%$. Bagi perusahaan yang baru berdiri dengan menerapkan teknologi iron making yang juga relatif baru di dunia, produk SRK PT MJIS cukup prospektif untuk dijadikan substitusi bahan baku utama PT KS seperti Direct Reduction Iron (DRI) atau scrap. Sejak tahun 2015, PT MJIS telah berhenti operasional, namun tahun 2018, PT KS akan menghidupkan kembali proyek PT MJIS, meski PT Antam menyatakan mundur.

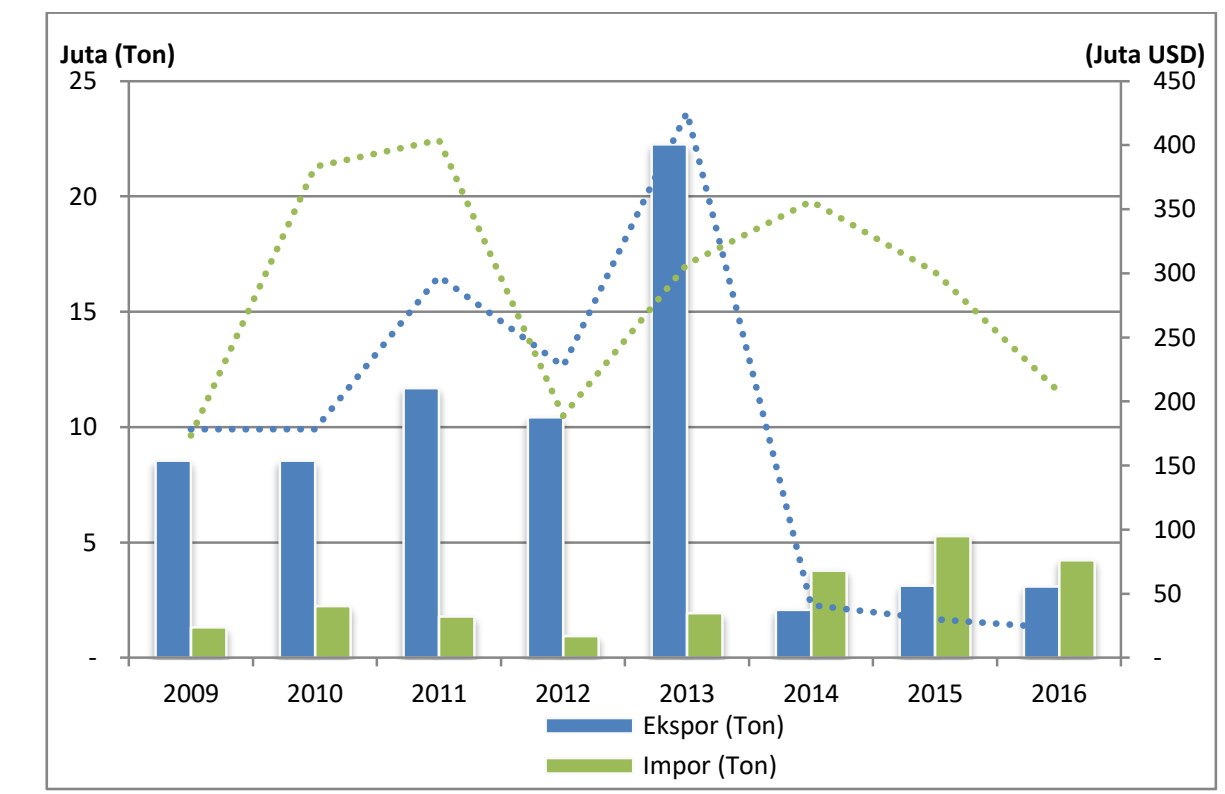

Sumber : Direktur Industri Material Dasar Logam (2015) dan Badan Pusat Statistik (2016) (diolah kembali)

Gambar 3. Neraca perdagangan bijih dan konsentrat besi di Indonesia 

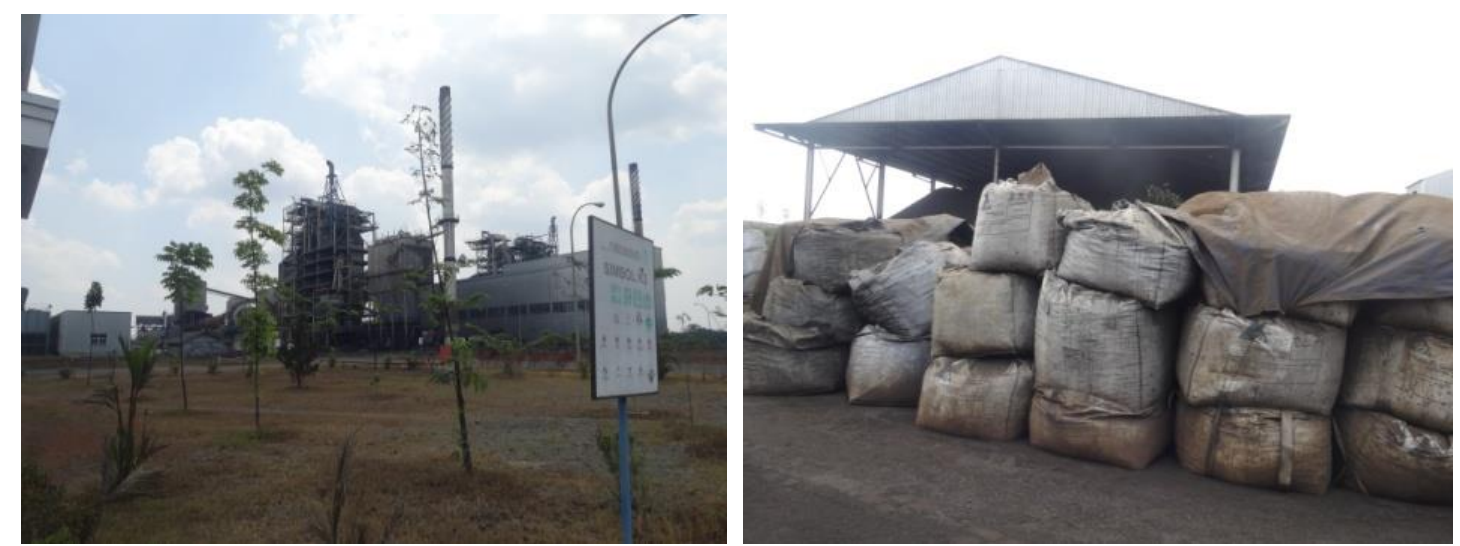

Gambar 4. PT Meratus Jaya Iron \& Steel (PT MJIS) Kabupaten Tanah Bumbu (PT Meratus Jaya Iron \& Steel, 2015)

Perusahaan smelter besi lainnya adalah PT PT DPS terletak di zona pengembangan ekonomi \pm 112 km dari Banjarmasin, Kalimantan Selatan. PT DPS memproduksi sponge iron atau dikenal sebagai Direct Reduced Iron (DRI) dan memulai produksi pada awal 2013 dengan 2 unit kiln berkapasitas 175 ton per hari menghasilkan output sponge iron ukuran $>3 \mathrm{~mm}$ dan 5-20 mm dengan kadar Fe 88$92 \%$ total sebesar 100.000 ton per tahun. Perusahaan ini masih terkendala dengan pasokan bahan baku dari tambang yang ada di sekitarnya sehingga belum bisa bekerja maksimal, baru mencapai sekitar 50\%. Kesulitan bahan baku terjadi karena perusahaan peleburan tersebut tidak memiliki tambang sendiri.

Permasalahan dari kedua perusahaan tersebut di atas, adalah kesulitan mendapatkan kualitas bijih besi yang dipersyaratkan sebagai bahan baku. Seperti PT MJIS mensyaratkan bahan baku dari jenis primary lump ore yang memiliki Fe total di atas 62\%. Mengolah kualitas bijih besi yang rendah, mengakibatkan biaya energi sangat besar. Sehingga harga produk sponge iron tersebut tidak ekonomis pada proses lanjutannya di PT KS. Oleh karena itu dibutuhkan teknologi alternatif dan inovatif untuk mengatasi masalah ini.

\section{Baja Kasar}

Sementara ini, industri baja kasar di Indonesia masih menggunakan bahan baku berupa pellet dan scrap yang diimpor. PT KS sebagai salah satu industri besi baja kasar nasional mengimpor pellet berkualitas tinggi dengan spesifikasi kimia dan fisik tertentu, berkadar minimum 65\% Fe, sebanyak sekitar 2,5 juta ton per tahun dan akan mencapai 4 juta tahun pada akhir 2020. Proses produksi baja di PT KS dimulai pada pabrik pembuatan besi yang menggunakan proses reduksi langsung bijih besi dengan gas alam. Hasil produksi yang berupa besi sponge ini selanjutnya dilebur bersama dengan scrap pada proses pembuatan baja yaitu pabrik baja slab dan pabrik baja billet. Proses pembuatan baja tersebut menggunakan teknologi dapur busur listrik yang dilanjutkan dengan proses pengecoran kontinu menjadi baja slab dan baja billet. Di samping PT KS, ada PT Krakatau Posco, telah berproduksi secara komersial dimulai pada pada 2013, yang memproduksi bahan baku baja berupa slab sebanyak 3 juta ton per tahun, setengahnya diproses menjadi plate. PT Krakatau Posco menggunakan teknologi Blast Furnace yang pertama di Indonesia.

Produksi baja kasar nasional (billet, slab, ion/steel cast) dari tahun ke tahun menunjukkan perkembangan yang berarti. Selama 2004-2009, produksi besi/baja kasar tumbuh rata-rata hanya $1,89 \%$ per tahun. Namun selama 2010-2017 produksinya tumbuh rata-rata 6,11\% pertahun. Pada 2017 diperkirakan sekitar 6,5 juta ton. Tingkat utilisasi yang masih rendah ini mendorong pemenuhan kebutuhan besi baja kasar nasional melalui impor. Impor besi baja kasar diperkirakan meningkat $12,04 \%$ pertahun, sehingga pada 2017 sekitar 6,5 juta. (Gambar 5). 


\section{Batang dan Batang Kawat Baja (Bars and Wire Rod)}

Di sektor industri antara, seperti produk wire rod, sejak 2004 berfluktuatif cenderung menurun hingga 2009. Sejak 2010 hingga sekarang trennya meningkat cukup signifikan
(Gambar 6). Pada 2017 diperkirakan mencapai sekitar 1,3 juta ton. Tingkat produksi ini masih belum mampu memenuhi kebutuhan nasional wire rod yang mencapai 2,0 juta ton pada 2017. Kekurangan tersebut ditutupi oleh impor.

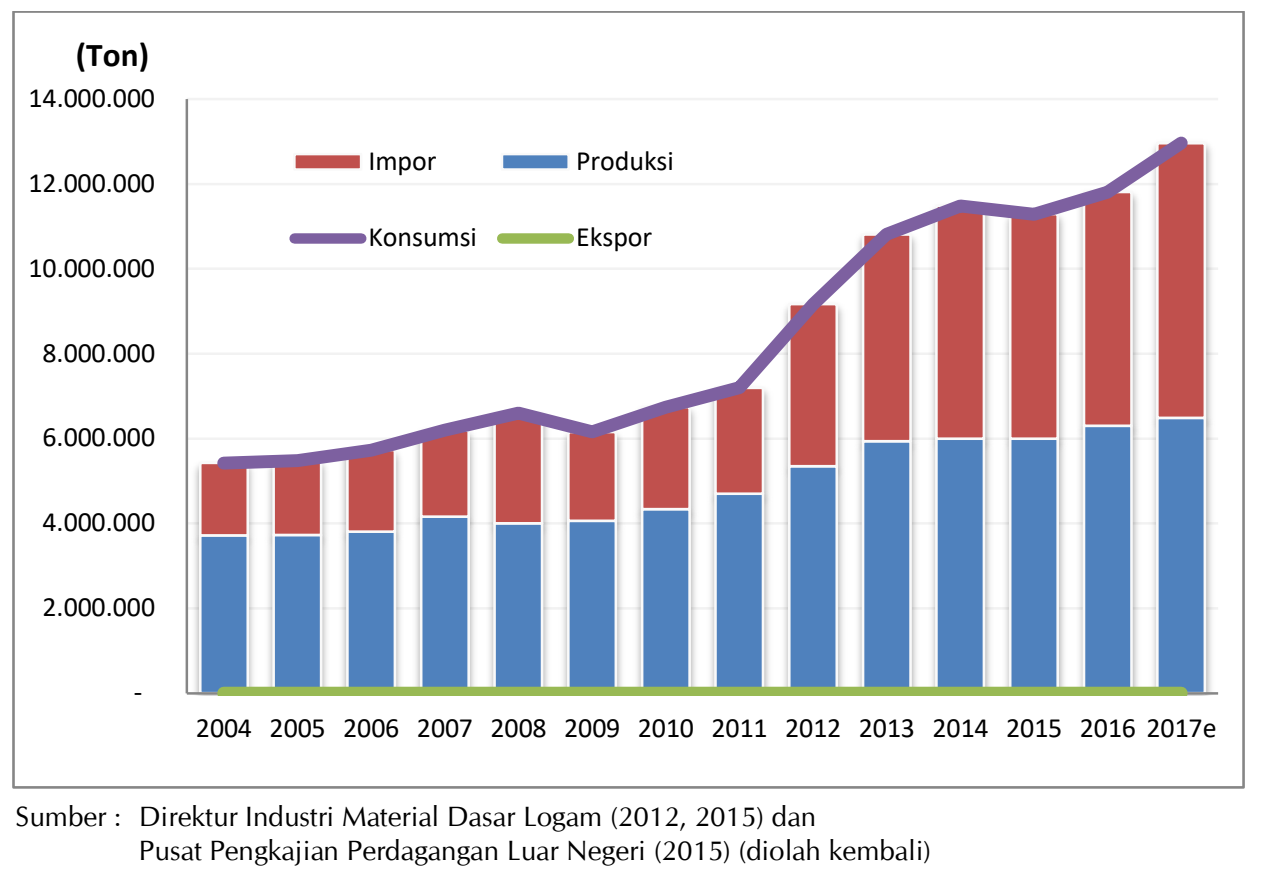

Gambar 5. Perkembangan produksi, impor, ekspor dan konsumsi baja kasar di Indonesia

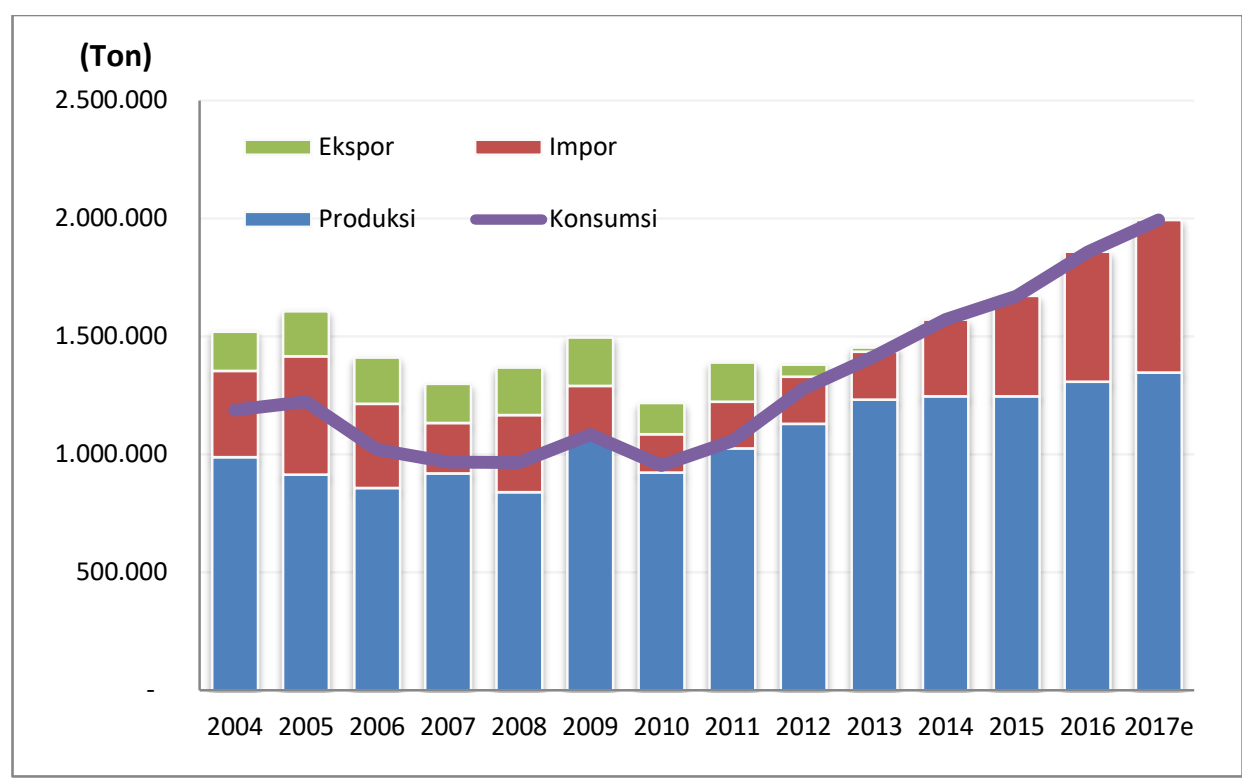

Sumber : Direktur Industri Material Dasar Logam $(2012,2015)$ dan

Pusat Pengkajian Perdagangan Luar Negeri (2015) (diolah kembali)

Gambar 6. Perkembangan produksi, impor, ekspor dan konsumsi bar dan wire rod di Indonesia 


\section{Hot Rolled Coil/Plates (HRC/P)}

Selain itu, produk hot rolled coil/plates (HRC/P) juga menunjukkan perkembangan yang berarti. Konsumsi nasional produk HRC/P meningkat signifikan selama tahun 2004-2017 sebesar $11,2 \%$ per tahun. Produksi HRC/P yang mencapai 5,8 juta ton di tahun 2017, baru dapat memenuhi $60,0 \%$ kebutuhan $\mathrm{HRC} / \mathrm{P}$ nasional yang mencapai 9,6 juta ton. Selebihnya, kebutuhan HRC/Plates nasional dipenuhi melalui impor. Impor produk HRC/P juga mengalami peningkatan hingga mencapai 3,9 juta ton di tahun 2017 (Gambar 7).

\section{Produk Akhir Besi Baja}

Konsumsi nasional akan produk hilir atau produk akhir besi baja semakin meningkat seiring dengan berkembangnya kebutuhan masyarakat. Besarnya proyek infrastruktur pemerintah dan tren kenaikan harga baja diperkirakan mendongkrak penjualan baja maupun profitabilitas perusahaan-perusahaan di subsektor manufaktur ini. Di samping itu ada multiple effect ke kebutuhan yang lain seperti otomotif yang relatif stabil. Adapun proyek-proyek yang saat ini sudah berjalan antara lain proyek swasta dan BUMN berupa jalan tol dan tower listrik. Tahun 2017, pasar baja domestik diperkirakan sekitar 14 juta ton, hampir dua kali lipat dibanding 10 tahun terakhir (Gambar 8). Dari sisi volume, pasokan baja dari pemain lokal mengalami kenaikan, tetapi dari prosentase relatif tetap sekitar 53,7\%.

\section{Perkembangan Investasi Pembangunan Pabrik Pengolahan Besi Baja}

Saat ini, Indonesia sedang mengembangkan pembangunan pabrik pengolahan dan pemurnian hasil tambang (peleburan) sejalan dengan amanah UU No 4 Tahun 2009 yang dijabarkan dalam Permen ESDM No 25 Tahun 2018. Berdasarkan data Direktorat Jenderal Mineral dan Batubara (2016), hingga Tahun 2016, fasilitas pemurnian existing ada 2 perusahaan, yaitu PT DPS dan PT MJIS, dengan investasi masing-masing USD 40 juta dan USD 150 juta. Sedangkan yang masih pembangunan (plan) ada 7 perusahaan dengan total investasi USD 535,370 juta (Tabel 4 dan 5).

Pembangunan berbahan baku bijih besi lokal telah dipelopori oleh PT MJIS yang merupakan perusahaan patungan antara PT Krakatau Steel Tbk dan PT Aneka Tambang Tbk. Konsep bisnis yang akan diterapkan oleh PT MJIS adalah mengolah bijih besi yang dipasok dari tambang-tambang marjinal untuk menghasilkan produk berupa besi sponge dan selanjutnya diolah menjadi baja di PT KS. Di samping itu, PT DPS, telah selesai membangun pabrik peleburan besi sponge berkapasitas 100 ribu ton per tahun dengan nilai investasi USD 40,0 juta.

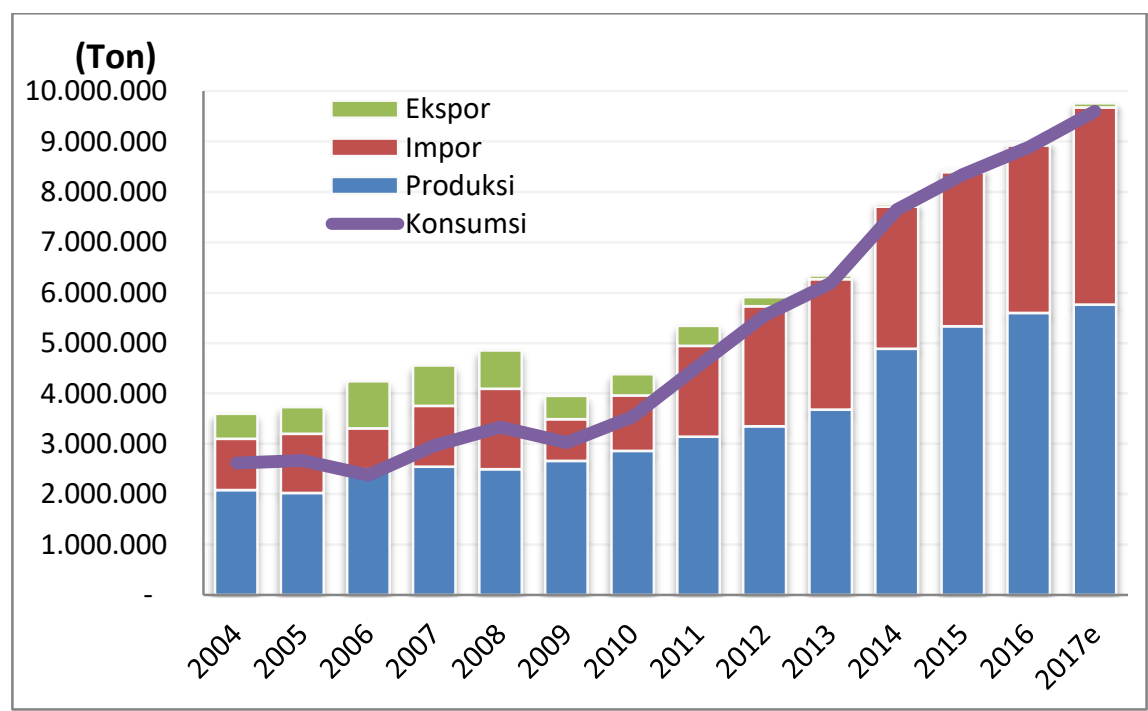

Sumber : Direktur Industri Material Dasar Logam $(2012,2015)$ dan Pusat Pengkajian Perdagangan Luar Negeri (2015) (diolah kembali)

Gambar 7. Perkembangan produksi, impor, ekspor dan konsumsi hot rolled coil/plates di Indonesia 


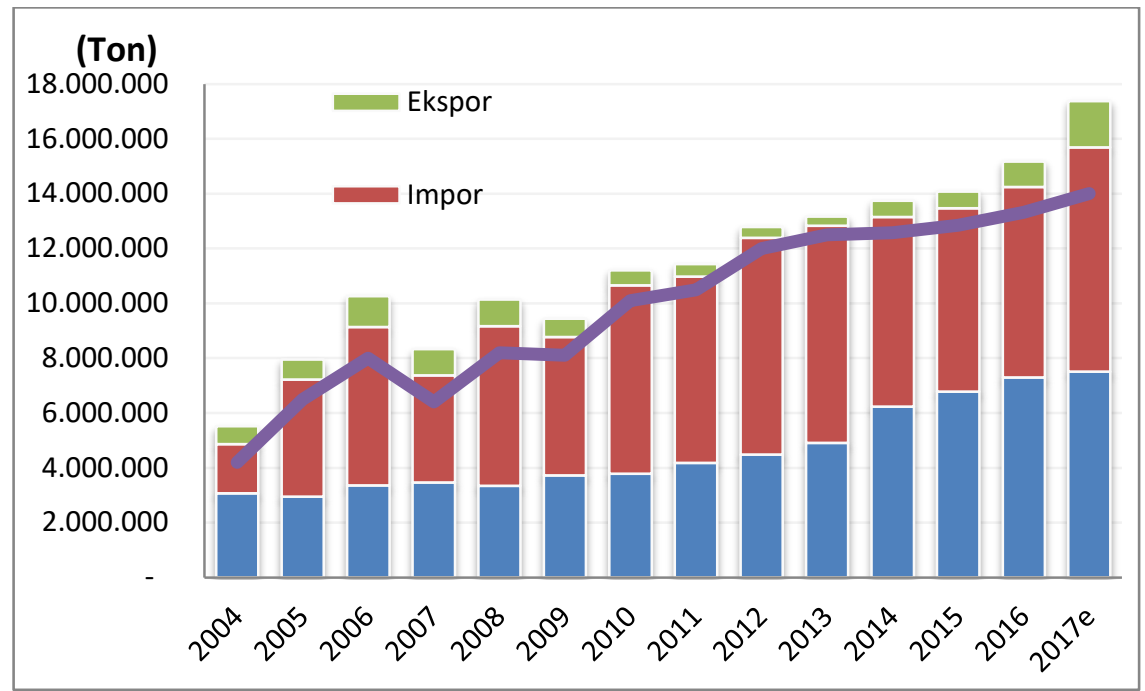

Sumber : Direktur Industri Material Dasar Logam $(2012,2015)$ dan Pusat Pengkajian Perdagangan Luar Negeri (2015) (diolah kembali)

Gambar 8. Perkembangan produksi, impor, ekspor dan konsumsi baja di Indonesia

Tabel 4. Fasilitas pemurnian besi yang ada

\begin{tabular}{|c|c|c|c|c|c|c|c|c|}
\hline \multirow[b]{2}{*}{ No. } & \multirow[b]{2}{*}{ Perusahaan } & \multirow[b]{2}{*}{ Produk } & \multirow[b]{2}{*}{$\begin{array}{c}\text { Jenis } \\
\text { Perizinan }\end{array}$} & \multicolumn{2}{|c|}{ Kapasitas Input } & \multirow[b]{2}{*}{$\begin{array}{l}\text { Investasi } \\
\text { (USD) }\end{array}$} & \multirow[b]{2}{*}{ Progres } & \multirow{2}{*}{$\begin{array}{l}\text { Waktu } \\
\text { Penye- } \\
\text { lesaian }\end{array}$} \\
\hline & & & & Bijih (ton) & $\begin{array}{l}\text { Konsentrat } \\
\text { (ton) }\end{array}$ & & & \\
\hline 1 & PT DPS & Steel & IUI & 1.10 & 220.000 & 000 & $100 \%$ & 2011 \\
\hline 2 & PT MJIS & Besi sponge, slab, billet & IUI & 3.300 .000 & 660.000 & 150.000 .000 & $100 \%$ & 2013 \\
\hline
\end{tabular}

Keterangan : Kedua perusahaan tersebut sementara tidak beroperasi

Sumber : Direktorat Jenderal Mineral dan Batubara (2016)

Tabel 5. Fasilitas pemurnian besi plan

\begin{tabular}{|c|c|c|c|c|c|c|c|c|}
\hline \multirow[b]{2}{*}{ No. } & \multirow[b]{2}{*}{ Perusahaan } & \multirow[b]{2}{*}{ Produk } & \multirow{2}{*}{$\begin{array}{c}\text { Jenis } \\
\text { Perizinan }\end{array}$} & \multicolumn{2}{|c|}{ Kapasitas Input } & \multirow{2}{*}{$\begin{array}{l}\text { Investasi } \\
\text { (USD) }\end{array}$} & \multirow[b]{2}{*}{ Progres } & \multirow{2}{*}{$\begin{array}{c}\text { Waktu } \\
\text { Penyelesaian }\end{array}$} \\
\hline & & & & Bijih (ton) & $\begin{array}{l}\text { Konsentrat } \\
\text { (ton) }\end{array}$ & & & \\
\hline 1 & PT SILO & Besi sponge & IUP OP & 6.300 .000 & 4.939 .200 & 170.000 .000 & $92 \%$ & 2017 \\
\hline 2 & PT SBP & Pig iron & IUP OPK & 240.000 & 50.000 & 120.000 .000 & $35 \%$ & 2017 \\
\hline 3 & PT MIS & Pig iron & IUP OP & 1.200 .000 & 900.000 & 73.000 .000 & $54 \%$ & 2018 \\
\hline 4 & PT MMP & Pig iron & IUP OP & 6.300 .000 & 5.400 .000 & 86.570 .000 & $83 \%$ & 2018 \\
\hline 5 & PT RS & Besi sponge & IUP OPK & 3.000 .000 & 600.000 & 4.400 .000 & $5 \%$ & 2018 \\
\hline 6 & PT QEP & Besi sponge & IUP OPK & 2.000 .000 & 400.000 & 8.400 .000 & $8 \%$ & 2018 \\
\hline 7 & PT JMI & Pig iron & KK & 3.000 .000 & 600.000 & 73.000 .000 & $6 \%$ & 2019 \\
\hline & Total & & & 22.040 .000 & 12.889 .000 & 535.370 .000 & & \\
\hline
\end{tabular}

Sumber : Direktorat Jenderal Mineral dan Batubara (2016)

Di samping pembangunan fasilitas pengolahan dan pemurnian, juga di hilirnya ada pengembangan pembangunan industri baja 10 juta ton di kawasan Cilegon, yaitu PT Krakatau Posco, yang merupakan perusahaan patungan PT KS dan Posco Korea. Yang sudah ada (2013) PT Krakatau Posco sudah memproduksi dengan kapasitas penuh 3 juta ton slab, sebagiannya
1,5 juta diolah lagi menjadi pelat. Kapasitas produksi 10 juta ton terbagi dalam tiga fasilitas produksi, yaitu produksi dua pabrik HSM berkapasitas 4,5 juta ton dan 4 juta ton serta pabrik pelat baja berkapasitas 1,5 juta ton. Bahan baku produksi tiga pabrik di atas akan dipasok dari pabrik peleburan biji besi PT KS yang berkapasitas 3 juta ton dan pabrik 
Krakatau Posco yang kapasitasnya rencananya ditingkatkan menjadi 6 juta ton, dan sebuah pabrik slab berkapasitas 1 juta ton. MoU Posco dan Krakatau Steel juga mencantumkan rencana pengembangan tiga pabrik baja canai dingin yang masing-masing berkapasitas 1,3 juta ton, 1,2 juta ton, dan 1,5 juta ton. Selain itu, akan ada peningkatan kapasitas produksi dari pabrik milik PT KS sebesar 1 juta ton crude steel. PT KS rencananya mengembangkan produksi baja lembaran 1,5 juta ton dan dapat dikembangkan hingga 3 juta ton. Pabrik tersebut senilai USD 460 juta ditargetkan rampung pada 2019. Di samping itu PT Krakatau Nippon Steel Sumikin merupakan kerjasama investasi antara PT KS dengan perusahaan Jepang, tengah membangun pabrik baja lapis galvanis untuk otomotif. Progress pembangunan pabrik berkapasitas 500 ribu ton per tahun tersebut ditargetkan rampung kuartal III-2017. PT KS juga tengah berkerja sama dengan PT Osaka Steel membangun PT Krakatau Osaka untuk produk baja kategori long product yang lebih berkualitas ke konsumen domestik. PT Krakatau Osaka di targetkan selesai pembangunannya pada tahun 2018, sehingga 2019 bisa berproduksi optimal dengan kapasitas 500 ribu ton per tahun (Tabel 6).

\section{Analisis Kinerja Rantai Industri Besi Baja melalui Nilai Tambah}

Terkait analisis keterkaitan hulu-hilir industri besi baja perlu dianalisis kinerja dari setiap rantai nilainya. Salah satu cara pengukuran kinerja adalah dengan menghitung nilai tambah. Untuk komprehensifnya pengukuran kinerja, selain perhitungan nilai tambah, diperhitungkan pula besarnya nilai penerimaan negara dan serapan tenaga kerja yang dibutuhkan. Adanya nilai tambah yang dihasilkan dari proses rantai industri besi baja menunjukkan baiknya kinerja rantai nilai (pasokan) besi baja.

Secara umum, nilai tambah (value added) pengolahan/pemurnian mineral adalah pertambahan nilai sebagai hasil dari proses pengolahan dan/atau pemurnian mineral. Keterkaitan dengan rantai nilai, maka dapat diperluas dengan adanya keterkaitan dengan hulu (bahan baku dari proses penambangan) dan keterkaitan hilir (yang memproses lebih lanjut pada industri antara/hilir). Dalam proses pengolahan nilai tambah dapat didefinisikan sebagai selisih antara nilai produk dengan nilai biaya bahan baku dan input lainnya, tidak termasuk tenaga kerja. Dengan perkataan lain, nilai tambah proses pengolahan dari bijih nikel menjadi produk olahan dapat diperoleh dengan menjumlahkan seluruh komponen yang merupakan variabel nilai tambah, yaitu biaya tenaga kerja, pajak dan retribusi (royalti), pendapatan bunga, selisih kurs positif, dana bantuan ke daerah atau masyarakat, dan keuntungan perusahaan. Untuk sampai kepada analisis setiap mata rantai nilai besi, akan didasarkan simulasi berdasarkan data hasil kegiatan survai lapangan (studi kasus).

\section{Analisis Peningkatan Nilai Tambah}

Untuk memperoleh gambaran tentang peningkatan nilai tambah mineral melalui pengolahan dan pemurnian besi akan dilakukan simulasi pengukurannya. Pengukuran peningkatan nilai tambah besi dilakukan untuk mengetahui sampai sejauh mana pengolahan dan pemurnian bijih besi menjadi besi sponge memberikan nilai tambah lebih jika dibandingkan dengan hanya melakukan penambangan bijih besi. Simulasi perhitungannya didasarkan pada sumber dari PT Lhoong Setia Mining dan PT MJIS serta sumber lainnya (Suherman, 2016a). Adapun untuk simulasi perhitungan nilai tambah dari penambangan bijih besi, diasumsikan tingkat produksi 1 juta ton bijih besi per tahun, sedangkan untuk pengolahannya menjadi besi sponge diasumsikan tingkat produksi 315 ribu ton per tahun. Dari hasil simulasi perhitungan, diperoleh nilai tambah dari aktivitas penambangan sebesar USD 6,99 juta per tahun atau USD 6,99 per ton bijih besi (Tabel 7). Sedangkan dari aktivitas pengolahan bijih besi menjadi besi sponge adalah sebesar USD 10,889 juta per tahun, atau sebesar USD 34,68 per ton (Tabel 8). Hal ini berarti bahwa setiap ton besi sponge yang dihasilkan memberikan peningkatan nilai tambah (lebih) daripada apabila hanya menambang bijih besi, sebesar 4,96 kali. 
Tabel 6. Perusahaan eksisting dan proyek investasi pembangunan pabrik baja di Indonesia

\begin{tabular}{|c|c|c|c|c|c|c|c|}
\hline $\begin{array}{c}\text { Nama } \\
\text { Perusahaan }\end{array}$ & $\begin{array}{l}\text { Kapasitas } \\
\text { Saat ini }\end{array}$ & Produk & Kapasitas & Produk & $\begin{array}{l}\text { Nilai } \\
\text { Investasi } \\
\text { (USD } \\
\text { Juta) }\end{array}$ & $\begin{array}{l}\text { Tenaga } \\
\text { Kerja } \\
\text { (orang) }\end{array}$ & $\begin{array}{l}\text { Target } \\
\text { Selasai }\end{array}$ \\
\hline $\begin{array}{l}\text { PT Karakatau } \\
\text { Steel }\end{array}$ & 2.400 .000 & $\begin{array}{l}\text { besi sponge, } \\
\text { slab, HRC,HSM }\end{array}$ & 3.400 .000 & $\begin{array}{l}\text { besi sponge, slab, } \\
\text { HRC,HSM,dll }\end{array}$ & & 5.780 & \\
\hline $\begin{array}{l}\text { PT Karakatau } \\
\text { Posco }\end{array}$ & 3.000 .000 & slab, pelat, & 6.000 .000 & $\begin{array}{l}\text { Slab, Pelat, HRC, } \\
\text { HSM }\end{array}$ & 6.000 & 8.500 & 2019 \\
\hline $\begin{array}{l}\text { PT Gunung } \\
\text { Group }\end{array}$ & & & 1.000 .000 & slab, HRC,HSM & 220 & 1.417 & 2016 \\
\hline $\begin{array}{l}\text { Lainnya (11 } \\
\text { Perusahaan)* }\end{array}$ & 3.270 .000 & slab, HRC,HSM & 3.270 .000 & slab, HRC,HSM & & 4.633 & \\
\hline $\begin{array}{l}\text { PT Krakatau } \\
\text { Osaka }\end{array}$ & & & 500.000 & $\begin{array}{l}\text { baja tulangan, baja } \\
\text { profil, baja C, dan } \\
\text { flat bar }\end{array}$ & 220 & 170 & 2018 \\
\hline $\begin{array}{l}\text { PT Krakatau } \\
\text { Nippon Steel } \\
\text { Sumikin } \\
\end{array}$ & & & 500.000 & $\begin{array}{l}\text { Komponen } \\
\text { produksi otomotif }\end{array}$ & 405 & 280 & 2017 \\
\hline Jumlah & 8.670 .000 & & 14.670 .000 & & 6.845 & 20.779 & \\
\hline
\end{tabular}

Keterangan : menggunakan bahan baku berupa scrap yang juga diimpor

Tabel 7. Nilai tambah penambangan bijih besi

\begin{tabular}{|c|c|c|c|c|}
\hline No. & Uraian & $\begin{array}{l}\text { Aliran Kas } \\
\text { (USD) }\end{array}$ & $\begin{array}{l}\text { Nilai Tambah } \\
\text { Per Ton (USD) }\end{array}$ & $\begin{array}{c}\text { Penerimaan Negara } \\
\text { Per Ton (USD) }\end{array}$ \\
\hline \multirow[t]{2}{*}{1.} & Pendapatan & 17.000 .000 & & \\
\hline & Iron Ore Lump@17 \$ USA 1.000.000 Ton & 17.000 .000 & & \\
\hline \multirow[t]{5}{*}{2.} & Pengeluaran Gaji \& Upah & 910.000 & 0,91 & \\
\hline & a. Gaji (net) Manajemen & 239.133 & & \\
\hline & b. Upah (net) Tenaga Kerja Langsung & 534.367 & & \\
\hline & c. PPh Manajemen & 42.200 & & 0,042 \\
\hline & d. PPh. Tenaga Kerja Langsung & 94.300 & & 0,096 \\
\hline 3. & ATK & 2.500 & & \\
\hline \multirow[t]{3}{*}{4.} & Bahan Bakar \& Pelumas & 1.745 .290 & & \\
\hline & a. Bahan Bakar & 1.545 .290 & & \\
\hline & b. Pelumas & 200.000 & & \\
\hline 5. & Suku Cadang & 300.000 & & \\
\hline 6. & Depresiasi \& Amortisasi & 2.182 .333 & & \\
\hline \multirow[t]{4}{*}{7.} & Royalti, CSR, Asuransi & 722.132 & 0,72 & \\
\hline & a. Royalti & 637.500 & & 0,638 \\
\hline & b. CSR ke Desa, dll & 6.375 & & \\
\hline & c. Asuransi Karyawan \& Jamsostek & 78.257 & & \\
\hline \multirow[t]{3}{*}{8.} & Lingkungan \& Reklamasi & 70.000 & & \\
\hline & a. Lingkungan & 35.000 & & \\
\hline & b. Reklamasi & 35.000 & & \\
\hline \multirow[t]{3}{*}{9.} & Pengangkutan \& Pemuatan (Sewa) & 5.000 .000 & & \\
\hline & a. Angkutan Tongkang ke Vessel & 2.500 .000 & & \\
\hline & b. Muat ke Vessel & 2.500 .000 & & \\
\hline \multirow[t]{10}{*}{10.} & Jasa Surveyor & 200.000 & 0,20 & \\
\hline & a. Biaya SGS / Analisis Conto & 100.000 & & \\
\hline & b. Analisis \& Draf Survey Ekspor & 100.000 & & \\
\hline & Jasa Lainnya & 65.000 & 0,07 & \\
\hline & a. Bea Cukai & 2.500 & & \\
\hline & b. Representasi & 10.000 & & \\
\hline & c. Dept. Pertambangan & 5.000 & & \\
\hline & d. Angkatan Laut & 2.500 & & \\
\hline & e. Pemda & 10.000 & & \\
\hline & f. Polisi & 2.500 & & \\
\hline
\end{tabular}




\begin{tabular}{|c|c|c|c|c|}
\hline No. & Uraian & $\begin{array}{c}\text { Aliran Kas } \\
(\text { USD })\end{array}$ & $\begin{array}{l}\text { Nilai Tambah } \\
\text { Per Ton (USD) }\end{array}$ & $\begin{array}{c}\text { Penerimaan Negara } \\
\text { Per Ton (USD) }\end{array}$ \\
\hline & g. Penguasa Pelabuhan & 2.500 & & \\
\hline & h. Perjalanan & 30.000 & & \\
\hline 11. & Biaya Over Head & 1.180 .445 & & \\
\hline 12. & Surplus Usaha Bruto & 4.922 .300 & & \\
\hline 13. & PPh Badan & 1.476 .690 & 1,48 & 1,477 \\
\hline 14. & Surplus Usaha Bersih & 3.445 .610 & 3,45 & \\
\hline & Bunga Bank ( $5 \%$ / Tahun) & 172.281 & 0,17 & \\
\hline 16. & Total Nilai Tambah Bijih Besi & & 6,99 & 2,25 \\
\hline
\end{tabular}

Tabel 8. Nilai tambah pengolahan bijih besi menjadi besi sponge

\begin{tabular}{|c|c|c|c|c|c|c|c|c|}
\hline No. & Uraian & Jumlah & Satuan & $\begin{array}{l}\text { Harga } \\
\text { (USD) }\end{array}$ & $\begin{array}{l}\text { Aliran Kas } \\
\text { (USD) }\end{array}$ & $\begin{array}{c}\text { Nilai } \\
\text { Tambah } \\
\text { (USD) }\end{array}$ & $\begin{array}{c}\text { Nilai } \\
\text { Tambah } \\
\text { Per Ton } \\
\text { (USD) }\end{array}$ & $\begin{array}{c}\text { Penerimaan } \\
\text { Negara } \\
\text { Per Ton } \\
(\text { USD) }\end{array}$ \\
\hline 1. & $\begin{array}{l}\text { Penjualan Produk Sponge } \\
\text { Iron }\end{array}$ & 315.000 & ton & 220 & 69.300 .000 & & & \\
\hline 2. & Bijih Besi (52 - 53 Fe) & 500.000 & ton & 17 & 8.500 .000 & & & \\
\hline 3. & Batubara $\geq 5.000$ k.kal & 400.000 & ton & 100 & 40.000 .000 & & & \\
\hline 4. & Batukapur $(\mathrm{Ca}=54 \%)$ & 21.600 & ton & 19 & 410.400 & & & \\
\hline 5. & Tenaga Kerja (net) & 273 & orang & 2.500 & 682.500 & 682.500 & 2,17 & \\
\hline 6. & PPh Karyawan $15 \%$ & & & & 102.375 & 102.375 & 0,33 & 0,33 \\
\hline 7. & Asuransi \& Jamsostek $10 \%$ & & & & 68.250 & 68.250 & 0,33 & \\
\hline 8. & BBM Solar Start Up & 80.000 & liter & 0,95 & 76.000 & & & \\
\hline 9. & Air PDAM $\left(116.640 \mathrm{~m}^{3}\right)$ & 90 & liter/detik & 0,20 & 23.328 & & & \\
\hline 10. & $\begin{array}{l}\text { Depresiasi (mesin, alat, } \\
\text { Plant } 15 \text { thn) }\end{array}$ & & & & 2.333 .333 & & & \\
\hline 11. & Maintenance & & & & 1.750 .000 & & & \\
\hline 12. & Lain-lain & & & & 5.651 .000 & & & \\
\hline 13. & CSR & & & & 160.435 & 160.435 & 0,51 & \\
\hline 14. & Surplus Usaha & & & & 9.542 .379 & & & \\
\hline 15. & PPh Badan & & & & 2.862 .714 & 2.862 .714 & 9,09 & 9,09 \\
\hline 16. & Surplus Usaha Neto & & & & 6.679 .665 & 6.679 .665 & 21,21 & \\
\hline 17. & Bunga Bank (5 \% / Tahun) & & & & 333.983 & 333.983 & 1,06 & \\
\hline & Jumlah & & & & 7.013 .649 & 10.889 .922 & 34,68 & 9,41 \\
\hline
\end{tabular}

Sumber : Hasil Pengolahan (simulasi)

Pendirian pengolahan bijih besi lokal menjadi reduced iron atau sponge iron akan memberikan beberapa manfaat yang sangat besar yaitu :

1. Kebutuhan akan bahan baku dalam pembuatan baja berupa sponge iron dapat terpenuhi, dengan pemanfaatan sekitar 500 ribu ton bijih besi lokal untuk mensubstitusi impor sebesar 315 ribu ton besi sponge (asumsi harga USD 220/ton) sehingga terjadi penghematan devisa sekitar USD 69,3 juta.

2. Sekitar 273 tenaga kerja langsung dari aktivitas pabrik pengolahan bijih besi. Tantangan dalam recruitment adalah pengutamaan penggunaan tenaga lokal dalam rangka pengendalian masuknya tenaga kerja asing dari tenaga kerja kasar sampai tenaga ahli. Hal tersebut sejalan dengan pendapat Soelistijo (2013) bahwa nilai tambah ini menciptakan efek ganda (antara lain menciptakan lapangan kerja) yang dapat diukur dengan penggandaan dan keterkaitan ekonomi. Di samping pengutamaan penggunaan tenaga kerja lokal juga pengutamaan penggunaan barang sebagai input produksi (Saleh dan Suherman, 2017).

3. Pemerintah mendapat penerimaan pajak dari adanya pabrik pengolahan bijih besi menjadi besi sponge (PPh karyawan dan PPh Badan) sekitar USD 9,41 juta per tahun. Hal ini sejalan dengan yang ditegaskan Haryadi (2011), bahwa melalui 
peningkatan nilai tambah mineral secara langsung akan mendorong peningkatan perolehan penerimaan negara dari pajak dan royalti akibat tingginya harga dan nilai produk tambang.

Di sisi lain peningkatan nilai tambah rantai besi baja dari parameter harga disajikan pada Gambar 8. Terlihat nilai tambah baja cukup panjang mulai dari penambangan bijih besi, pengolahan dan pemurnian menjadi sponge iron, slab, HRC, CRC, hingga galvanized sheet. Hal ini sejalan dengan yang ditegaskan Djamaluddin, Thamrin dan Achmad (2012) dan Yunianto (2014), bahwa untuk dapat menjadi barang jadi, bahan tambang memerlukan rantai proses yang cukup panjang dengan masing-masing tahap proses merupakan proses peningkatan nilai tambah.

\section{Analisis Prospek Pengembangan Smelter dan Rantai Nilai Besi Baja}

Langkah yang diambil pemerintah untuk menghentikan ekspor bijih mineral tanpa melalui proses pengolahan dan pemurnian dinilai beralasan kuat. Jelas dari tujuannya, peningkatan nilai tambah sebenarnya diarahkan untuk memberikan keuntungan bagi seluruh pemangku kepentingan, yaitu bagi perusahaan tambang berupa peningkatan nilai jual produk olahan; bagi perusahaan industri manufaktur berupa ketersediaan bahan baku yang berasal dari dalam negeri domestik yang diharapkan lebih murah dan terjamin; bagi masyarakat luas berupa ketersediaan lapangan kerja dan kesempatan berusaha baru akibat dibangunnya pabrik pengolahan/pemurnian; dan bagi pemerintah berupa peningkatan penerimaan negara. Di sisi lain, penerapan UU No. 4 Tahun 2009 tentang pertambangan mineral dan batubara tersebut juga menimbulkan permasalahan pada perusahaan yang masih belum membangun pabrik peleburan. Menghadapi permasalahan tersebut, pemerintah mengeluarkan kebijakan untuk memberikan tenggang waktu selama tiga tahun melalui Peraturan Pemerintah No 1 Tahun 2014 dan Permen ESDM No 1 Tahun 2014 serta disusul dengan Peraturan Pemerintah No 1 Tahun 2017 dan Permen ESDM No 5 Tahun 2017 tentang Peningkatan Nilai Tambah Mineral Melalui Kegiatan Pengolahan dan Pemurnian Mineral di Dalam Negeri, masih mengizinkan ekspor mineral olahan atau konsentrat selama lima tahun dengan syarat antara lain mempunyai progess pembangunan smelter pengolahan dan pemurnian. Sesuai Permen ESDM No 5 Tahun 2017, kadar minimum konsentrat besi laterit $50 \%$ dan kadar $\left(\mathrm{Al}_{2} \mathrm{O}_{3}+\mathrm{SiO}_{2}\right) \quad 10 \%$ (Menteri Energi dan Sumber Daya Mineral, 2017).

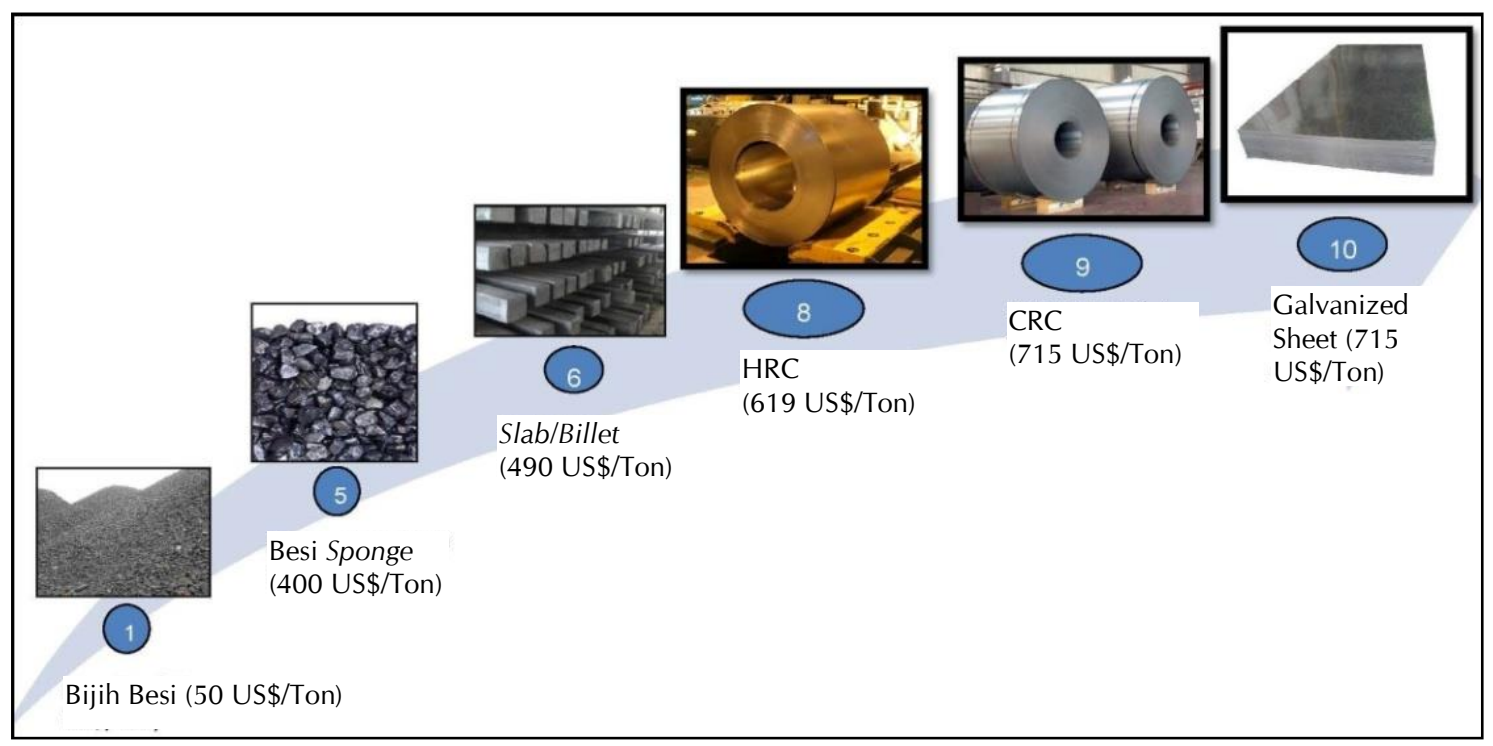

Sumber : Direktur Industri Material Dasar Logam (2015).

Gambar 8. Nilai tambah besi baja di Indonesia 
Dengan dikeluarkan kebijakan tersebut adalah momen yang baik menarik investor dari China, India dan Jepang untuk mengembangkan smelter dan industri hilir berbasis besi yang potensinya masih besar. Untuk itu, perlu didukung oleh pengembangan insfrastruktur antara lain pembangtit listrik PLTU dan potensi pembangkit sumberdaya lokal (Permana, 2010). Demikian pula perlu mendorong peran bank sebagai agent of development dalam hal ini untuk menyalurkan kredit kepada perusahaan industri baja nasional yang membutuhkan pendanaan (Mahadewi dan Winarko, 2012). Di samping itu, teknologi yang disarankan Zulhan (2013) untuk mengolah bijih besi Indonesia adalah teknologi direct reduction berbasis batubara (rotary kiln) atau blast furnace untuk pabrik dengan kapasitas besar. Hal yang positif telah dan sedang dikembangkan pengembangan konsep cluster industri berbasis besi seperti di Kalimantan Selatan dan Wilayah Cilegon, Banten. Pengembangan pola kerjasama PT KS dengan mintra investor, antara lain yang sudah berhasil adalah PT Krakatau Posco dan disusul oleh PT KOS.

Apabila semua target pembangunan smelter besi dapat terealisasi hingga 2020 akan diproduksi rantai sponge iron dan pig iron sekitar 13,769 juta ton dengan dukungan bahan baku rantai bijih besi sekitar 26,440 juta ton. Kondisi tersebut sejalan dengan rantai berikutnya yaitu produksi baja kasar/semi finished product ditargetkan pada 2020 sekitar 14,670 juta ton. Perkiraan nilai produk bijih besi sekitar USD 1,322 miliar, nilai tambah sekitar USD 184,816 juta dan serapan tenaga kerja sekitar 55.083 orang. Perkiraan nilai produk smelter besi sekitar USD 5,508 miliar, nilai tambah sekitar USD 586,009 juta dan serapan tenaga kerja sekitar
15.036 orang. Demikian pula di rantai semi finished product baja akan tercipta nilai ekonomi sekitar USD 8,802 miliar, nilai tambah USD 936,533 miliar, dan tenaga kerja sekitar 20.799 orang (Tabel 9).

\section{Dampak Rantai Nilai Besi Baja Terhadap Perekonomian Nasional}

Untuk mengetahui dampak setiap mata rantai industri besi terhadap perekonomian nasional, maka diperlukan data Produk Domestik Bruto (PDB) sebagai nilai pembanding (pembagi).

Berdasarkan data PDB 2014 - 2017 (Badan Pusat Statistik, 2018), dapat diperkirakan pada 2020, PDB Sektor Pertambangan dan Penggalian sebesar USD 57.497.378.147 (dengan mengasumsikan rata-rata nilai tukar yang berlaku Rp. 13.900 per dolar), PDB Sektor Industri Pengolahan USD 171.601.614.871, dan PDB Total USD 825.378.690.606. Dengan menyandingkan hasil perhitungan nilai tambah setiap rantai industri besi dengan PDB tersebut, maka dapat diketahui besarnya kontribusi yang diberikan.

Kontribusi ini diperkirakan akan meningkat secara signifikan apabila target pembangunan smelter dan industri antara terwujud pada 2020 nanti. Kontribusi penambangan bijih besi terhadap Sektor Pertambangan dan Penggalian diperkirakan meningkat 0,321\% atau 0,022\% terhadap PDB Nasional. Kontribusi pengolahan/ pemurnian bijih besi diperkirakan meningkat $0,341 \%$ terhadap Sektor Industri Pengolahan atau 0,071\% terhadap PDB Nasional, dan kontribusi industri baja kasar/semi finished product diperkirakan 0,546\% terhadap Sektor Industri Pengolahan atau $0,113 \%$ terhadap PDB Nasional.

Tabel 9. Nilai ekonomi rantai industri besi baja di Indonesia, tahun 2020

\begin{tabular}{lcccc}
\hline \multicolumn{1}{c}{ Rantai Industri Besi Baja } & $\begin{array}{c}\text { Produksi } \\
\text { (ton) }\end{array}$ & Nilai (USD) & $\begin{array}{c}\text { Nitai Tambah } \\
\text { (USD) }\end{array}$ & $\begin{array}{c}\text { Tenaga Kerja } \\
\text { (orang) }\end{array}$ \\
\hline Industri Penambangan & 26.440 .000 & 1.322 .000 .000 & 184.815 .600 & 55.083 \\
Industri Smelter besi & 13.769 .000 & 5.507 .600 .000 & 586.008 .640 & 15.036 \\
Industri Baja Kasar/Semi Finished Product & 14.670 .000 & 8.802 .000 .000 & 936.532 .800 & 20.779 \\
\hline Total & & 15.631 .600 .000 & 1.707 .357 .040 & 90.898 \\
\hline
\end{tabular}

Sumber : Hasil analisis 


\section{KESIMPULAN}

Pelaksanaan pembangunan smelter besi di rantai industri hulu industri besi baja nasional masih terkendala antara lain dengan keberadaan teknologi yang belum dapat mengoptimalkan bahan baku bijih besi lokal kadar rendah. Hal ini berimbas pada rantai antara dan rantai akhir indutri baja nasional yang tidak dapat mensubstitusi impor bahan baku, padahal kemajuan pengembangan dan pembangunan di kedua rantai industri tersebut cukup berhasil. Tantangan PT SILO adalah mengolah bijih besi kadar rendah, dengan teknologi dan inovasi yang layak secara finansial. PT SILO perlu didorong untuk menghasilkan bahan baku yang mempunyai nilai ekonomi untuk proses pengolahan menjadi sponge iron (PT MJIS dan PT DPS). Apabila tantangan pada teknologi pengolahan pemurnian bijih besi ini dapat ditangani dan rencana pembangunan dan pengembangan rantai industri baja dapat terealisasi, maka untuk 2020 akan tercipta total nilai ekonomi sekitar USD 15,632 miliar, nilai tambah USD 1,707 miliar, dan serapan tenaga kerja sekitar 86.266 orang. Adanya rantai industri hulu-hilir yang saling terkait dalam industri besi baja diharapkan struktur industri Indonesia akan semakin kuat dan ketergantungan akan besi baja impor dapat dikurangi.

Keberadaan industri-industri berbasis besi tersebut akan mendongkrak perekonomian secara nasional. Pada 2020 kontribusi industriindustri berbasis besi secara keseluruhan sebesar 0,207\% terhadap PDB Nasional.

\section{REKOMENDASI}

Dari hasil kajian direkomendasikan hal-hal sebagai berikut :

1. Perlu inovasi untuk menghasilkan teknologi pengolahan bijih besi kadar rendah, atau mengadopsi teknologi dari negara yang selama ini mengolah bijih besi Indonesia. Hal tersebut dapat dilakukan oleh investor dan atau lembaga riset/litbang yang terkait.

2. Untuk mengoptimalkan kineja rantai nilai besi baja, di samping inovasi teknologi khususnya dipengolahan bijih besi kadar rendah, juga perlu menekankan untuk mengutamakan penggunaan tenaga kerja lokal. Demikian pula untuk mengutamakan penggunaan input barang dan jasa dalam aktivitas produksinya. Hal tersebut sejalan amanat UU No. 4/2009 pasal 106 dan PP 23 pasal 86-88, tentang keharusan perusahaan pertambangan menggunakan tenaga kerja, barang dan jasa lokal.

3. Pengembangan pabrik smelter dengan konsep cluster industry berbasis besi seperti di Kalimantan Selatan, sebagaimana sudah dipelopori oleh PT MJIS dan PT DPS memproduksi besi sponge dan PT SILO yang baru tahap produksi konsentrat bijih besi perlu didorong untuk terus maju berkembang. Demikian pula perlu didorong PT KS untuk terus mengembangkan kemitraan dengan investor untuk mengembangkan industri antara dan industri akhir besi baja.

4. Pembuatan regulasi untuk mendorong sinerginya rantai industri, perlu didukung dengan kajian Domestic Market Obligation (DMO) Hulu dan DMO Hilir, yaitu pengutamaan pemasokan kebutuhan bahan baku untuk industri pengolahan dan pengutamaan produk pengolahan sebagai bahan baku industri hilir.

\section{DAFTAR PUSTAKA}

Badan Pusat Statistik (2016) Data ekspor-impor bijih besi tahun 2009 - 2016. Badan Pusat Statistik.

Badan Pusat Statistik (2018) Produk domestik bruto nasional, tahun 2014 - 2017. Badan Pusat Statistik.

Direktorat Jenderal Mineral dan Batubara (2016) Progres pembangunan dan investasi fasilitas pemurnian. Jakarta: Direktorat Jenderal Mineral dan Batubara.

Direktur Industri Material Dasar Logam (2012) Konsumsi, utilisasi \& ratio produksi terhadap konsumsi produk industri logam. Jakarta.

Direktur Industri Material Dasar Logam (2015) FGD penyelarasan roadmap industri dan pasar baja nasional. Jakarta: Direktorat Jenderal Basis Industri Manufaktur. Available at: 
https://bkti-pii.or.id/fgd-penyelarasanroadmap-industri-dan-pasar-baja-nasional/.

Djamaluddin, H., Thamrin, M. and Achmad, A. (2012) "Potensi dan prospek peningkatan nilai tambah mineral logam di Indonesia (Suatu kajian terhadap upaya konservasi mineral)," in Prosiding Hasil Penelitian Fakultas Teknik. Bandung: Institut Teknologi Bandung, pp. TG3-1-TG3-14. Available at: http://download.portalgaruda.org/article.php? article $=94526 \& \mathrm{val}=2170$.

Haryadi, H. (2011) "Analisis peranan mineral dan batubara bagi perekonomian nasional," Jurnal Teknologi Mineral dan Batubara, 7(3), pp. 122-136. Available at:

http://jurnal.tekmira.esdm.go.id/index.php/mi nerba/article/view/823.

Haryadi, H. and Saleh, R. (2012) "Analisis keekonomian bijih besi Indonesia," Jurnal Teknologi Mineral dan Batubara, 8(1), pp. 116. Available at: http://jurnal.tekmira.esdm.go.id/index.php/mi nerba/article/view/802.

Hasni and Manulang, H. (2011) "Peran sektor baja dalam perekonomianIndonesia," Buletin Ilmiah Litbang Perdagangan, 5(1), pp. 22-46. doi: 10.30908/bilp.v5i1.119.

Ishlah, T. (2009) "Potensi bijih besi Indonesia dalam kerangka pengembangan klaster industri baja," Buletin Sumber Daya Geologi, 4(2), pp. 11-21. Available at:

http://buletinsdg.geologi.esdm.go.id/index.ph

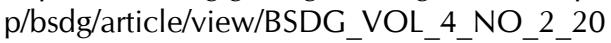
$09 \_$.

Kementerian Perindustrian (2013) "Hilirisasi meningkatkan potensi industri nasional," Media Industri, p. 66. Available at: http://www.kemenperin.go.id/download/5011.

Mahadewi, L. and Winarko, H. B. (2012) "Tinjauan analisis pembiayaan sektor perbankan untuk industri baja nasional," Journal of Capital Market and Banking, 1(2), pp. 20-40. Available at:

http://adlermanurungpress.com/journal/datajo urnal/Vol 1 No 2/Tinjauan Analisis Pembiayaan Sektor Perbankan.pdf.

Menteri Energi dan Sumber Daya Mineral (2017) Peraturan Menteri Energi dan Sumber Daya Mineral Republik Indonesia Nomor 5 Tahun 2017 tentang Peningkatan Nilai Tambah Mineral melalui Kegiatan pengolahan dan Pemurnian Mineral di Dalam Negeri.
Pardiarto, B. (2009) "Tinjauan rencana pembangunan industri besi baja di Kalimantan Selatan," Buletin Sumber Daya Geologi, 4(2), pp. 1-13. Available at: http://psdg.bgl.esdm.go.id/buletin_pdf_file/Bu I Vol 4 no. 2 thn 2009/1. bijih besi industi baja 1.pdf.

Pardiarto, B. (2011) "Peluang bijih besi dalam pemenuhan kebutuhan komoditas mineral strategis nasional," Buletin Sumber Daya Geologi, 6(2), pp. 59-70.

Permana, D. (2010) "Tantangan dalam peningkatan nilai tambah mineral dan batubara," Jurnal Teknologi Mineral dan Batubara, 8(4), pp. 412.

Presiden Republik Indonesia (2009) Undangundang Republik Indonesia Nomor 4 Tahun 2009 tentang pertambangan mineral dan batubara. Indonesia. Available at: http://peraturan.go.id/uu/nomor-4-tahun2009.html.

PT Meratus Jaya Iron \& Steel (2015) "Kunjungan Komisi I DPRD Provinsi Kalimantan Selatan," p. 20.

Purnama, A. B. and Subarna, Y. S. (2016) "Pendugaan area prospek bijih besi dengan metoda geomagnet dari eksplorasi geofisika di Daerah 'ABC' Kabupaten Katapang, Kalimantan Barat," in Santoso, B., Ardha, N., Umar, D. F., Rochani, S., Husaini, Madiutomo, N., Ningrum, N. S., Wahyudi, T., Damayanti, R., and Handayani, S. (eds.) Prosiding Kolokium Puslitbang Teknologi Mineral dan Batubara 2016. Bandung: Puslitbang tekMIRA, pp. 295-302.

Pusat Pengkajian Perdagangan Luar Negeri (2015) Analisis kebijakan pengamanan perdagangan produk besi baja nasional. Jakarta. Available at: http://bppp.kemendag.go.id/laporan_hasil_an alisis/view/ODU\%3D.

Pusat Sumber Daya Mineral Batubara dan Panas Bumi (2017) "Sumber daya dan cadangan pertambangan Indonesia." Jakarta: Pusat Sumber Daya Mineral Batubara dan Panas Bumi, p. 21.

Saleh, R. and Suherman, I. (2017) "Analisis penetapan target local content barang pada kegiatan usaha pertambangan," Jurnal Teknologi Mineral dan Batubara, 13(2), pp. 141-152.

doi: 10.30556/jtmb.Vol13.No2.2017.175. 
Soelistijo, U. W. (2013) "Beberapa indikator nilai tambah ekonomi Indonesia," Jurnal Teknologi Mineral dan Batubara, 9(1), pp. 35-49. Available at:

http://jurnal.tekmira.esdm.go.id/index.php/mi nerba/article/view/777.

Suherman, I. (2016a) "Analisis tekno-ekonomi pengembangan smelter nikel di Indonesia," in Santoso, B., Ardha, N., Umar, D. F., Rochani, S., Husaini, Madiutomo, N., Ningrum, N. S., Wahyudi, T., Damayanti, R., and Handayani, S. (eds.) Prosiding Kolokium Puslitbang Teknologi Mineral dan Batubara 2016. Bandung: Puslitbang tekMIRA, pp. 117-131.

Suherman, I. (2016b) "Analisis teknoekonomi pengembangan pabrik peleburan bijih besi dalam rangka memperkuat industri besi baja di Indonesia," Jurnal Teknologi Mineral dan Batubara, 12(1), pp. 23-44. doi: 10.30556/jtmb.Vol12.No1.2016.229.

Suherman, I., Pramusanto, Sudjarwanto, Suseno, T., Jafril and Saefudin, R. (2011) Kajian teknoekonomi dan kebijakan peningkatan nilai tambah bauksit, nikel, bijih besi, mangan dan anode slime. Bandung: Puslitbang tekMIRA.
USGS (2018) Mineral commodity summaries 2018. Reston, Virginia. Available at: https://minerals.usgs.gov/minerals/pubs/mcs/2 018/mcs2018.pdf.

Usman, D. N. (2015) Ketersediaan Potensi Endapan Bijih Besi Indonesia Dalam Mendukung Industri Besi Dan Baja Nasional, www.academia.edu. Available at: https://www.academia.edu/26528984/Keterse diaan Potensi Endapan Bijih Besi Indonesia _dalam_Mendukung_Industri_Besi_dan_Baja_ $\bar{N}$ asional (Accessed: August $\overline{14}, 20 \overline{1} 8$ ).

Yunianto, B. (2014) "Analisis dampak penerapan kebijakan nilaitambah mineral Indonesia terhadap ekspor dan tenaga kerja," Jurnal Teknologi Mineral dan Batubara, 10(3), pp. 127-141. Available at: http://jurnal.tekmira.esdm.go.id/index.php/mi nerba/article/view/729.

Zulhan, Z. (2013) "Aspek teknologi dan ekonomi pembangunan pabrik pengolahan bijih besi menjadi produk baja di Indonesia," Metalurgi, 28(2), pp. 105-120. doi: 10.14203/metalurgi.v28i2.252. 